\title{
DISCLAIMER
}

3 report was prepared as an account of work sponsored by an agency of the United States rernment. Neither the United States Government nor any agency thereof, nor any of their ployees, makes any warranty, express or implied, or asumes any legal liability or responsity for the accuracy, completencas, or usefulness of any information, apparatus, product, or cess disclosed, or represents that its use would not infringe privately owned rights. Refere herein to any spocific commercial product, process, or service by trade name, trademark, sufacturer, or otherwice does not necesarily constitute or imply its endorsement, recomdation, or favoring by the United States Government or any agency thereof. The views opinions of authors expresed bercin do not necesurily state or reflect those of the ted States Government or any afency thereof.

\section{Present and Future}

\section{Nuclear Power Generation as a Reflection of Individual Countries' Resources and Objectives}

\section{Y. Borg}

Manuscript Date: June 26, 1987

\section{LAWRENCE LIVERMORE NATIONAL LABORATORY University of California - Livermore, California - 94550}




\section{Contents}

Abbreviations of Reactor Types .........................................................................................................................

Abstract............................................................................................................................................................. 1

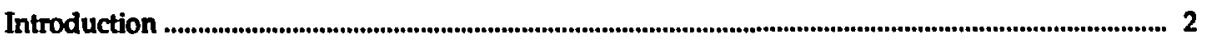

Global Overview ........................................................................................................................................................ 2

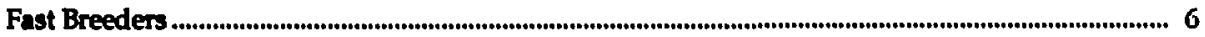

Soviet Union's Reactor Program ......................................................................................................................... 7

The COMECON Countries: Romania, Poland, Czechoslovakia, Bulgaria,

German Democratic Republic, and Hungary ............................................................................................... 9

The Impressive French Nuclear Power Industry .........................................................................................11

Nuclear Power in West Germany ........................................................................................................................14

The U.K.'s Aging Reactors: A Mediocre Recond but Indispénsable ........................................................... 15

The Swedish Dilemma: Abolishing Nuclear Reactors ......................................................................................17

Finland's Reactors Have an Excellent Recond ......................................................................................................... 18

Switzerland's Debate Over Nuclear Energy .......................................................................................................19

Nuclear Energy in Belgium and the Netiverlands: A Study in Contrasts ...............................................20

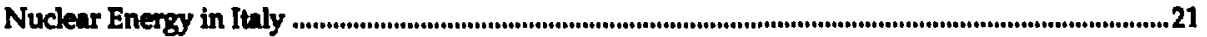

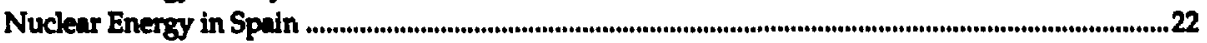

Nuciear Energy in Yugoshavia ..............................................................................................................................22

Non-Nuclear European Countries: Norway, Austria, Denmark,

Portugal, Greece, and Ireland..........................................................................................................................................23

Nuclear Power in Japan ..............................................................................................................................................24

The Nuclear Option in the Far East: Taiwan, Republic of Korea,

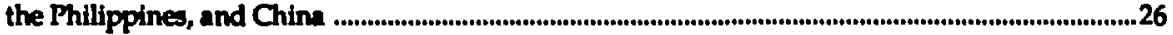

Three Maverick Nuclear States: India, Brazil, and Argentina ...................................................................27

Nuclear Energy in South Africa and Pakistan: Two More Maverick Nuclear States ............................29

Canada's Large Nuclear Program ......................................................................................................................30

Nuclear Reactors in Mexico: Without High Priority........................................................................................31

Conclusions ............................................................................................................................................................................31

Data Sources for Tables .............................................................................................................................................34

References ............................................................................................................................................................................35 


\section{Abbreviations of Reactor Types}

Countries of origin are indicated if applicable.

AGR

ATR

BHWR

BWR

CANDU

FBR

HTGR

LWGR

LWR

PHWR

PWR

RBMK
Advanced gas reactor (U.K.)

Advanced thermal reactor (Japan)

Boiling heavy-water-moderated reactor (Norway)

Boiling water reactor

Conadian deuterium-uranium reactor (Canada)

Fast breeder reactor

High-temperature gas reactor

Light-water graphite-moderated reactor

Light-water renctors

Premurized heavy-water-moderated reactor (Conada)

Pressurized water reactor

Light-water, graphite-moderated reactor (U.S.S.R.) 


\title{
Present and Future \\ Nuclear Power Generation \\ as a Reflection of \\ Individual Countries' \\ Resources and Objectives
}

\begin{abstract}
The nuclear reactor industry has been in a state of decline for more than a decade in most of the world. The reasons are numerous and often unique to the energy situation of individual countries. Two commonly cited issues influence decisions relating to construction of reactors: costs and the need, or lack thereof, for additional generating capacity. Public concern has "politicized" the nuclear industry in many non-commurist countries, causing a profound effect on the economics of the option. The nuclear installations and future plans are reviewed on a country-by-country basis for 36 countries in the light of the resources and objectives of each. Because oil and gas for power production throughout the world are being phased out as much as possible, coal-fired generation currently tends to be the chosen alternative to nuclear power production. Exceptions occur in many of the less developed countries that collectively have a very limited operating experience with nuclear reactors. The Chernobyl accident in the U.S.S.R. alarmed the public; however, national strategies and plans to build reactors have not changed markedly in the interim. Assuming that the next decade of nuclear power generation is uneventful, additional electrical demand would cause the nuclear power industry to experience a rejuvenation in Europe as well as in the U.S.
\end{abstract}




\section{Introduction}

The Chernobyl nuclear accident on April 26, 1986, had far-reaching consequences throughout the world. Health and environmental issues were foremost in the minds of most Europeans in the months immediately following the disaster. The safety of all nuclear reactors and associated facilities has been questioned by responsible authorities and the public in the ensuing months. Now, a year after the accident, it is possible to begin to ascess the impact of the incident on world opinion and on the development of the world's nuclear power industry. Such an assesament requires superimposing the Chernobyl accident on the situation that existed in the numerous nuclear countries at the time of the accident. That, in turn, is highly dependent both on the specific energy demands of individual countries as well as their finandal and energy resources. In recent years the subject of nuclear power production has become politicized in many countries, thereby adding a new dimension to its development and weceptability. Further, nuclear power has always hed international political ramifications because of possible diversion of nuclear muterials for weapons. Thus, at the time of Chernobyl, the status of the indigenous nuclear power industry in most countries was influenced by a complex group of issues often unique to each country.

Forty-one countries have active nuclear programs; of these, 29 have operable power reactors, another 6 have reactors under construction, and the remaining o have reactors in the planning stage. In the following text, the nuclear power industry is reviewed on a country-by-country basis. In addition, the points of vew of European non-nuclear nations-Australia, Norway, Ireland, Portugal, Greece, and Denmark - are examined.

The U.S. nuclear reactor industry is the largest in the world. Because the U.S. has supplied much of the world's nuclear technology, and its nuclear industry has become a hallmark for achievement, the U.S. experience plays an important part in this narrative. Furthermore, the U.S. nuclear industry, although regulated by the federal government, resides in the private industrial sector, strongly influenced by public opinion. UItimately, the collective views of both the U.S. nuclear industry and the nation's citizenry are reflected in worldwide developments.

\section{Global Overview}

At the end of 1986, there were 378 operating nuclear plants in the world, of which 97, or onequarter, were in the U.S. ${ }^{1}$ By 1990, the total is anticipated to reach 185, the U. S. having 116. Worldwide installed capacity by that time is estimated to increase from 266 GWe-net (December $31,1986)$ to 366 GWe-net, of which 105 GWe-net will be associnted with reactors within the U.S.' This recent estimate for the size of the U.S. industry in 1990 is vastly lower than earlier estimates by the U.S. Department of Energy (DOE) (see Table 1).

Estimates for world capacity by various agencies have also been progressively lowered over the same time span. For example, in 1976, the Edison Electric Institute forecast that world capacity under a moderate scenario would reach 570 GWe in 1985 and $1120 \mathrm{GW}$ by 1990.2 Compare those projections to actual world capacity in 1985 (May 31) of 239 GWe (see Ref. 3) and the current projection of 366 GWe for 1990.

Although the U.S. operates thelargest number of reactors in the world (Fig. 1), theircontribution to electrical generation in the U.S. on a percentage basis is far from the recond among the nuclear countries. The record belongs to France, where $70 \%$ of the power produced in 1986 was by nuclear means (Table 2).

Another way to view the degree to which various countries have turned to nuclear power generation is to measure it in terms of installed generating capacity per copita (Fig. 2). By this measure, Sweden is currently the leader and has been for some time. If we look at projected capacity for the year 1990, it appears that France will not be far behind.

In the four countries with the largest share of installed nuclear capucity, pressurized water reactors (PWR) are collectively the most prevalent design (Table 3). In fact, the PWR is the most common reactor throughout the world. Of approximately 394 operable power reactors and 160 under construction as of mid-1986, 304 are PWRs and 104 are boiling water reactors (BWR).

The PWRs also have a good safety record. Some of the publicly acknowledged nuclear meltdown accidents in the world are given in Table 4, with the type of reactor involved. 
Table 1. Past projections of U.S. Installed nuclear capacity. ${ }^{4-7}$

\begin{tabular}{|c|c|c|c|c|c|}
\hline \multirow{2}{*}{$\begin{array}{l}\text { Year of } \\
\text { forecast }\end{array}$} & \multirow{2}{*}{$\begin{array}{l}\text { Installed } \\
\text { capacity } \\
\text { in year of } \\
\text { forecast" } \\
\text { (GWe) }\end{array}$} & \multicolumn{3}{|c|}{ Capacity forecast (GWe) } & \multirow[b]{2}{*}{ Notes } \\
\hline & & 1985 & 1990 & 2000 & \\
\hline 1974 & 32 & 250 & 475 & 1090 & $\begin{array}{l}\text { Mid case (D), U.S. Atomic } \\
\text { Energy Commission }\end{array}$ \\
\hline 1977 & 16 & 127 & 195 & 380 & $\begin{array}{l}\text { Low care from Energy } \\
\text { Research and Development } \\
\text { Administration } \\
\text { adopted in National } \\
\text { Energy PIan }\end{array}$ \\
\hline 1981 & 56 & 93 & 127 & 170 & $\begin{array}{l}\text { Mid-estimate, Dept of } \\
\text { Energy /Grand Junction }\end{array}$ \\
\hline 1985 & 80 & - & 105 & 111 & $\begin{array}{l}\text { Upper reference case, Dept. } \\
\text { of Energy }\end{array}$ \\
\hline
\end{tabular}

- Summer capacity as of December 31.

Table 2. Nuclear power generation as a jercent of total power generation (1986)."

\begin{tabular}{lc}
\hline Country & Percent \\
\hline France & 70 \\
nelgium & 68 \\
Sweden & 51 \\
Korea & 44 \\
Taiwan & 44 \\
Finland & 10 \\
Switrerland & 39 \\
Spain & 31 \\
Weat Germany & 30 \\
Japan & 25 \\
U.K. & 20 \\
U.S. & 17 \\
Canads & 15 \\
U.S.S.R. & $10-11$ b \\
Netherlands & 6 \\
Yugoslavia & 5 \\
Italy & 5 \\
\hline Reference information for tables can be found \\
in the section "Source Data for Tables" at the end \\
of this report. & \\
Eutimated. & 5 \\
\hline
\end{tabular}




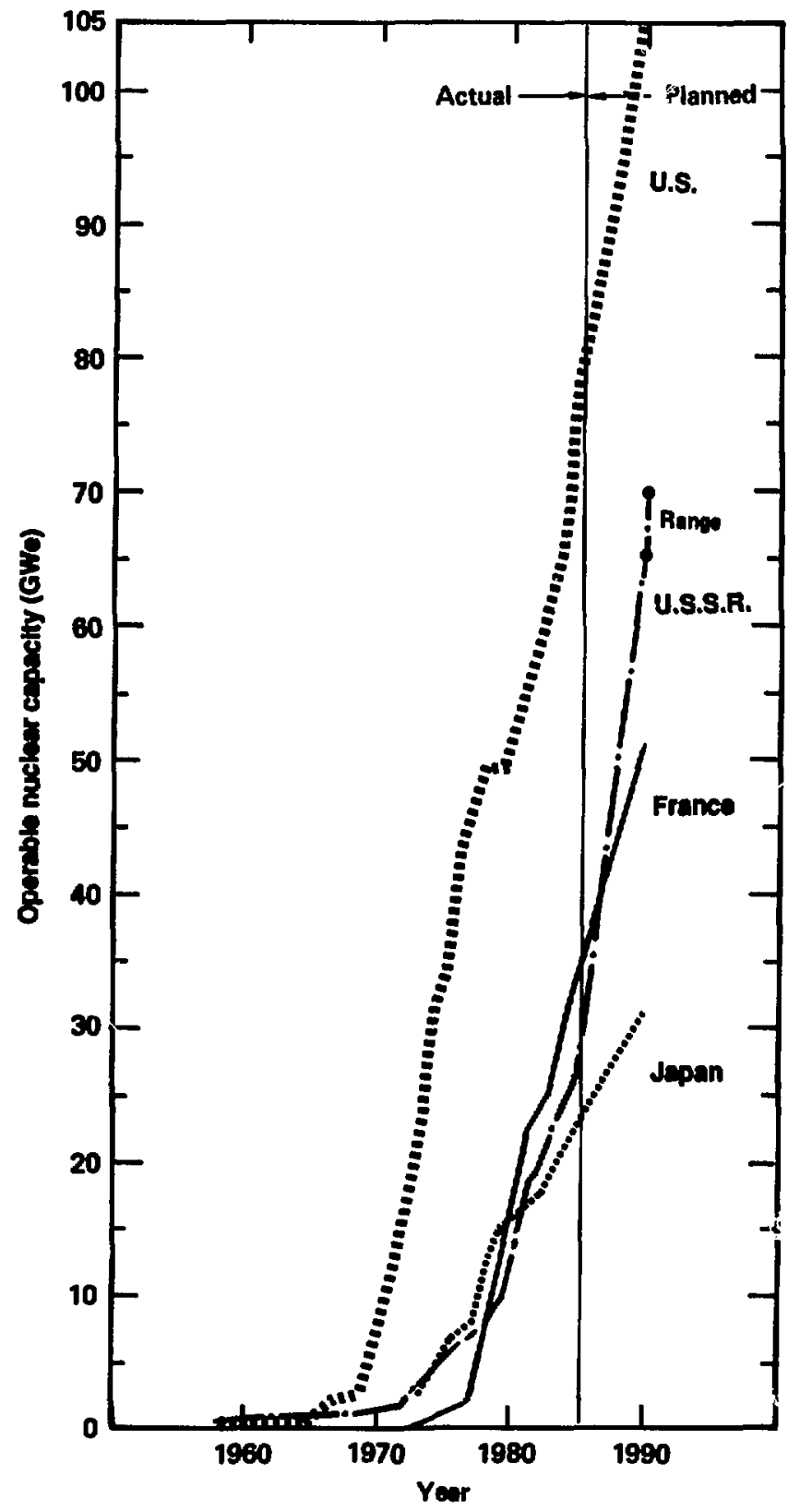

Figure 1. Projections of operable nuclear capacily in the U.S., U.S.S.R., France, and Japan."-1s 


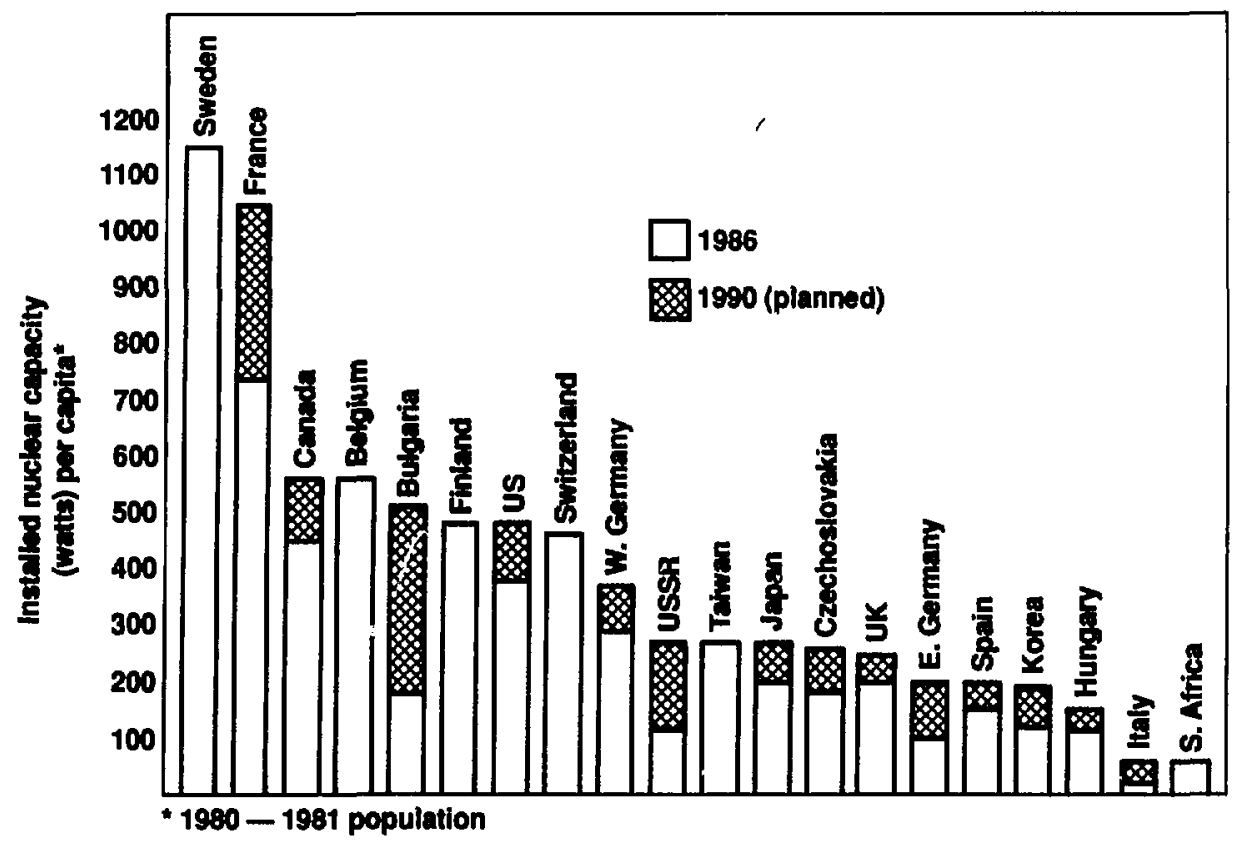

Figure 2. Installed nuclear capacity per capita.

Table 3. Types of power reactors in operation."

\begin{tabular}{lcccc}
\hline & \multicolumn{4}{c}{ Number of units } \\
\cline { 2 - 5 } Type of reactor & U.S. & France & U.S.S.R. & Japan \\
\hline Pressurized water (PWR) & 63 & 39 & 22 & 15 \\
Boiling water (BWR) & 33 & 0 & 1 & 16 \\
Magnox & 0 & 4 & 0 & 1 \\
Light water, graphite-moderated & 1 & 0 & $27^{\mathrm{c}}$ & 0 \\
(LWGR) & 1 & 0 & 0 & 0 \\
High-temperature gas & 2 & 2 & 5 & 2 \\
Misc. (FBR, etc) & & & & \\
\hline
\end{tabular}

\footnotetext{
Not including revearch and government-owned non-power producing reactors.

bmall natural uranium fueled, graphite-moderated, gas-cooled reactors that are being phaned out.

Includes Chemobyl 3 bat not 4
} 
Table 4. Examples of reactos accidents involving core meltdown. ${ }^{14}$

\begin{tabular}{lll}
\hline Reactor name & \multicolumn{1}{c}{ Type } & Year \\
\hline NRX (Canada) & Demonstration pressure tube & 1952 \\
EBR-1 (U.S.) & Experimental fast reactor & 1955 \\
Windscale (U.K.) & Plutonium production pile & 1957 \\
SL-1 (U.S.) & Experimental mobile reactor & 1961 \\
Enrico Fermi 1 (U.S.) & Demonstration fast reactor & 1966 \\
Chapelcross (U.K.) & Plutonium production reactor & 1966 \\
St Laurent (France) & Magnox & 1966 \\
Lucens (Switz.) & Experimental reactor & 1969 \\
Three Mile Isl 2 (U.S.) & PWR & 1979 \\
Chernobyl (U.S.S.R.) & LWGR (RBMaK) & 1986 \\
\hline
\end{tabular}

= Soviet dedignation is RDMK, which roughly tranolated is "hiph-power bolling water nactor:"

\section{Fast Breeders}

Fast breeders that use a mixture of plutonium and uranium-238, which in turn produces plutonium, produce more plutonium than they usehence, the name "breeder." At one time, they seemed to be the obvious answer to the problem of what to do with plutonium produced in fuel rods of conventional reactors. For that reason, many countries undertook their design, and twelve fast breeders now operate in the work. ${ }^{15}$ Tixe Soviet Union has two; France has the Super-Phenix (actually a joint French-German-Italian project); Germany and Great Britain have demonstration units; and there are research units in the U.S., U.S.S.R, Japan, and India. In addition, larger units (but less than $300 \mathrm{MWe}$ ) have been built in Japan, West Germany, and Italy, and are scheduled to begin operation in the next decade. 5 Fuel reprocessing plants, which produce plutonium, operate in the U.S., France, U.K., and U.S.S.R, and are under construction in Japan and West Germany.

Contrary to early predictions, the world demand for breeders and their fuel has greatly dimin- ished. The reasons are many: smailer growi , in electrical demand than predicted; unexpected lu'v prices for uranium that, in turn, reflect on the overestimation of the growth of nuclear power in the world with the attendant overestimation of uranium demand for the 1980 's and beyond; and, finally, the high cost of construction as judged by the French experience with the Super-Phenix. In this instance, the . Dst per kilowatt of this first-of-akind reactor is estimated to be about 2.2 times the cost ascociated with the standard French light water reactors.16 It is questionable whether the French will build another fast breeder reactor (FBR) in the forseeable future; they are not committed to build the special facilities required for reprocessing the core fuel in the Super-Phenix. Nonetheless, by early 1985, an estimated 60 metric tons of plutonium had been separated from spent fuel of conventional reactors. ${ }^{17}$ As that amount increases, the options for its use or disposal will again come up for discussion. 


\section{Soviet Union's Reactor Program}

To put the Soviet nuclear industry in perspective, Table 5 shows comparable background information for the U.S., U.S.S.R., and France.

The Chemobyl accident involved a light water graphite-moderated reactor (LWGR), RBMK series, fueled by $\mathrm{UO}_{2}$ enriched to $1.8 \%$. The LWGR, as seen in Table 6 , is one of the two standard reactors in the U.S.S.R. The acciderit involved Chernobyl 4, one of six planned for that vite. At this juncture, four are operating (or were), two were under construction, scheduled for completion in late 1986 and 1989. One year after the Chernobyl 4 accident, the Chairman of the State Committee for Peaceful Use of Atomic Energy announced that construction at Chernobyl 5 and 6 had been cancelled, and no more RBMK reactors would be constructed."

Not included in the tally of Table 6 are research and government-owned non-power producing reactors. The U.S. LWGR listed is power-

Table 5. Electrical generation In the U.S.S.R., U.S., and France (1986).

\begin{tabular}{llll}
\hline & U.S.S.R. & U.S. & France \\
\hline Total electrical generation (bn kWh) & 1560 & 2489 & 358 \\
Nuclear contribution (bn kWh) & 149 & 434 & 252 \\
Percent nuclear generation & $10-11^{\circ}$ & 17.4 & 70 \\
Installed nuclear capacity (GWe-net) & 30 & 86 & 40 \\
Number of operable power reactors & 55 & 100 & 45 \\
Number of reactors under construction & 37 & 25 & 17 \\
Annual nuclear capacity factor (\%) & n.a." & 58.6 & 67.3 \\
\hline
\end{tabular}

atimated from reported 1167 bn kwh for the firt nine monthe ${ }^{19}$ and from IAEA sata.

Not avillable.

Table 6. Types of power resctors in operation in the U.S.S.R., December 31, 1986.

\begin{tabular}{lccc}
\hline & \multicolumn{3}{c}{ Number of units } \\
\cline { 2 - 4 } Type of reactor & U.S.G.R. & France & U.S. \\
\hline Pressurized water (PWR) & $22(1.3 \mathrm{GW})$ & 63 & 39 \\
Boiling water (BWR) & $1(0.05 \mathrm{GW})$ & 33 & 0 \\
Magnox & 0 & 0 & 4 \\
Light-water, graphite-moderated & $27(14.7 \mathrm{GW})$ & 1 & 0 \\
High-temperature gas & 0 & 1 & 0 \\
Misc. (FBR, etc.) & $5(0.91 \mathrm{GW})$ & 2 & 2 \\
\hline
\end{tabular}

anall natural uraniom-fueled, graphlte-moderated, gav-cooled reactors that are being phased out.

Incladen diabled Chemobyl 3 bat not Chernobyl \&. 
producing Hanford N-reactor rated at $800 \mathrm{MWe}$. The only other graphite-moderated reactor in the U.S. is the high temperature gas reactor (HTGR) at Fort St. Vrain, Colorado, listed in Table 6.

Of the 27 LWGRs in the U.S.S.R., not including Chernobyl 4, 11 are under $100 \mathrm{MWe}$ and 2 are in the 100-200 MWe range (Table 7). These 13 are among the oldest reactors in the country. The largest of the group are basically the same as the Chernobyl design but obtain 50\% more power within the same physical dimensions by increasing the fuel enrichment to $2 \%$ uranium-235.

The RBMK-series reactor has never been exported because of its plutonium-producing capability, and operating planis are not frequently visited by foreigners.

The first Soviet reactor built with a containment structure was a PWR at Loviisa, Flnland, on the Gulf of Finland. The Westinghouse-designed containment was constructed at Finnish insistence. The first reactor to be built in the Soviet Union with a containment structure around it was PWR No. 5 at Novo-Voronezh in European Russia, which became operational in 1981 . The managers have been quoted about safety and containment structures:

"We have 2000 reactor-years experience total so far. And there hasn't been a single failure. The fifth unit at Novo-Voronezh will have a container as an experiment. But it is a vain expenditure of money," said Yuri Syvintsev, reactor safety director, Kurchatov Institute. ${ }^{20}$

"No leakages are possible." said Vidaly Sedov, plant manager at Novo-Voronezh resctor.20

The RBMK reactors are automated and use robots to k. $\mathrm{k}$ and unload fuel by remote controls and external television cameras. Fuel elements are usually transferred at night "when there are nut so many people at the plant." "11 The reactor is not shut downduring reloading. Apparently the Chernobyl disaster occurred at such a time. When asked about radiation hazards to the plant operators at the Smolensk RBMK nuclear stetion, which is identical to Unit No. 4 at Chemobyl, V. A. Popelkov, head of the section on radiation safety, replied, "Natural background radiation of uranium has no effect on

Table 7. U.S.S.R. graphite-moderated reactos (1986).

\begin{tabular}{|c|c|c|c|c|}
\hline Reactor & Number & $\begin{array}{c}\text { Ratins } \\
\text { (MWe-net) }\end{array}$ & $\begin{array}{c}\text { Total } \\
\text { (MWe-net) }\end{array}$ & Start-up date \\
\hline \multicolumn{5}{|l|}{ Operational reactor: } \\
\hline Obinsk & 1 & $\mathbf{5}$ & $\mathbf{5}$ & 1954 \\
\hline Troitsk 1-6 & 6 & 90 & 540 & 1958 \\
\hline Leningrad 14 & 4 & 950 & 3800 & $1974,-76,-80,-81$ \\
\hline Bllibino 1-4 & 4 & 11 & 14 & $1974-76$ \\
\hline Belogrark 1 and 2 & 2 & $102<175$ & 275 & 1964,67 \\
\hline Kunk 1-4 & 4 & 950 & 3800 & $1976,-79,-83,-86$ \\
\hline Smolensk 1 and 2 & 2 & 950 & 1900 & $1983,-85$ \\
\hline Chemobyl I-3 & 3 & 950 & 2850 & $1978,-79,-83$, \\
\hline Ignalinek 1 & 1 & 1450 & 1450 & 1984 \\
\hline Subtotal & 27 & & 14665 & \\
\hline \multicolumn{5}{|c|}{ Reactors under construction } \\
\hline Smolensk 3 & 1 & 950 & 950 & 1987 \\
\hline Ignalinak 2 & 1 & 1450 & 1450 & 1987 \\
\hline Total & 29 & & 17065 & \\
\hline
\end{tabular}

- Thece ere graphite-moderated bet sometimes clased a BWR. 
health-you can walk up and touch it." This statement appeared in Moscow Selskaya Zhizn, December $22,1985 .{ }^{21}$

The ambitious nuclear reactor program in the Soviet Union has not proceeded according to plan. By 1985 , installed nuclear capacity was to have reached $32 \mathrm{GWe}$, but it fell short. Thenext Five Year Plan calls for an additional $37 \mathrm{GWe}$ of installed capacity and more than double the nuclear output from $170 \mathrm{bn} k W h$ to 380 bn $k W h$ by 1990 . Part of the failure to achieve past goals is related to another disaster several years ago at Atommash, a reactor manufacturing plant on the Don River. The estimated $\$ \boldsymbol{A}$ billioi plant was designed to mass produce reactors on the two-and-one-half square-mile site. However, during construction it was discovered that the foundation was undermined, and part of the plant collapsed. Apparently the failure was caused by rising water table that, in turn, was caused by construction of dams on both the Volga and Don Rivers. Apparently the plant is now functioning, but its output has not been able to match planned expansion of the Soviet nuclear power industry.

A long-standing problem in the U.S.S.R. nuclear power industry has been selecting sites for plants. Despite vast land area, suitable sites for nuclear stations are scarce. Seismic considerations rule out vast portions of the Caucasus and Central Asia, while in European U.S.S.R., where the demand for power is highest, population considerations as well as scarcity of land and water now devoted to industry and agriculture limit the number of new sites. These considerations have dictated the concentration of nuclear power plants, fuel treatment plants, and waste disposal facilities to large complexes such as Chernobyl, Novo-Voronezh, etc. The increase in tho work force at these locations during construction of the many reactor units and related facilities, as well asduring routine maintenance and operation, mmpounds the potential toll from accidents such as Chemobyl.

\section{The COMECON* Countries:}

\section{Romania, Poland, Czechoslovakia, Bulgaria, German Democratic Republic, and Hungary}

Nuclear energy in the COMECON countries, with a few exceptions, has not contributed substantially to alleviate what have become chronic electrical shortages. The bulk or power in these countries is coal-generated or imported from the U.S.S.R. and islbania (see Table 8).

Acute shortages have occurred in Romania during the past two winters, which resulted in "militarization" of the domestic energy industry. In Romania, all the lignite coal-fired power plants are obsoleie, and in recent years sometimes half are inoperative or undergoing repairs; so every year since 1979, the government has decreed that domestic use of electricity be cut by anywhere from 20 to 50\%. Street lighting is no longer provided in the country and severely limited in the cities. During acute winter shortages, one room per residence could be lit with 15-W bulbs. Use of household appliances was banned in 1985, and state-run television was limited to one two-hour program daily. Room temperatures were officially fixed at $16^{\circ} \mathrm{C}\left(61^{\circ} \mathrm{F}\right)$, and during the harsh winter months they often fell below that level.

Apart from the breakdown of electrical generating plants, the responsibility for power shortages lies with the government and its overambitious economic development plans. Romania's industry, which is not reputed to be energy efficient, consumes approximately $84 \%$ of all electricity generated. The household sector has reduced its share to $6.4 \%{ }^{2}$ In an effort to end chronic electrical shortages, Romania has contracted with the Atomic Energy, Ltd., of Canada for construction of five 629-MWe Canadian deuterium-uranium

* COMECON (Council for Economic Mutual Assistance) is a loose organization that joins the Soviet Union and six Communist countries of Eastern Europe: Bulgaria, Czechoslovakia, the German Démocratic Republic, Hungary, Poland, ar: 1 Romania. It was created in 1949 to unite and coordinate economic progress and public welfare. 
Table 8. Nuclear power in the COMECON cointries (exclusive of the Soviet Union).

\begin{tabular}{|c|c|c|c|c|}
\hline Country & Year & $\begin{array}{l}\text { Installed } \\
\text { nuclear } \\
\text { capacity } \\
\text { (GWe-net) }\end{array}$ & $\begin{array}{c}\text { Percent } \\
\text { nuclear } \\
\text { generation } \\
\text { (1986) }\end{array}$ & $\begin{array}{l}\text { Population } \\
\text { (millions) }\end{array}$ \\
\hline Bulgaria & $\begin{array}{l}1986 \\
1990\end{array}$ & $\begin{array}{l}1.62 \\
4.49\end{array}$ & 31 & 8.7 \\
\hline Crechoslovakia & $\begin{array}{l}1986 \\
1990\end{array}$ & $\begin{array}{l}2.77 \\
3.94\end{array}$ & $21^{b}$ & 15.3 \\
\hline Dem. Rep. Germany & $\begin{array}{l}1986 \\
1990\end{array}$ & $\begin{array}{l}1.70 \\
3.33\end{array}$ & $12^{b}$ & 16.7 \\
\hline Hungary & $\begin{array}{l}1986 \\
1990\end{array}$ & $\begin{array}{l}1.22 \\
1.63\end{array}$ & 18 & 10.7 \\
\hline Poland & $\begin{array}{l}1986 \\
1990\end{array}$ & $\begin{array}{l}0 \\
0.44\end{array}$ & $\mathbf{0}$ & 35.0 \\
\hline Romania & $\begin{array}{l}1986 \\
1990\end{array}$ & $\begin{array}{l}0 \\
1.26\end{array}$ & 0 & 21.6 \\
\hline
\end{tabular}

a Population statiettes are from the 1975-19s1 period depending on the country.

b UEA eatimates.

(CANDU) reactors, the first of which is to be completed in 1989. Financing the reactors will prove troublesome. Romania's oil production, second only to that of the U.S.S.R. in the COMECON, has fallen in the last few years. Although Romania has been a net importer of oil since the 1970's, products produced at its refineries have been an important source of currency and a barter item in exchanges with the Soviet Union. An increasing problem in Romania as well as in other COMECON countries is the rising costs associated with construction of nuclear plants.

Historically, the COMECON countries have relied haavily on coal for power production. Production of coal and lignitein Poland and the Democratic Republic of Germany ranks behind that of the U.S., China, and the U.S.S.R. in the world, but on'y Poland's production is principally hard coal. Both Poland and Czechoslovakia have been net exporters in recent years. Substantial coal reserves within the COMECON are a partial explanation for the slow move toward nuclear energy. Almost all of the COMECON countries have a small amount of domestic gas and oil, but only Romania has quantities large enough to contribute substantially to domestic derrand.

The first commercial reactors to go into production in the COMECON outside of the U.S.S.R. were in Bulgaria and the Democratic Republic of
Germany in 1974. It was four years from the start of construction to commercial operation. By contrast, construction of reactors put into operalion in 1986started in 1976 and 1978 (Czechoslovakia) and 1979 (Hungary). All operative or planned reactors are PWRs of Soviet design, except for those under construction in Romania. As of June 1986, the cumulative lifetime load factors for Hungary's l'ak 1 and 2 reactors were ranked two and three in the world; however, this is in part a reflection on the relatively recent dates (1983-84) of their commissioning because newly commissioned reactors tend to have better performance records than reactors that have been in operation for decades. Also, information from other COMECON countries including the U.S.S.R. is usually not included in such tabulations because it is either not available or not up to date.

Most of the Eastern bloc countries have ambitious plans to displace fossil fuels with nuclear power stations. Collectively, $34.8 \mathrm{GWe}$ (net) of ariditonal nuclear capacity is planned to be operational by the turn of the century; of that total, 13.2 GWe is under construction." By the year 2000, COMECON installed capacity would beapproximately $42 \mathrm{GWe}$, one-and-one-half times the size of nuclear capacity in the U.S.S.R. by mid-1986. In view of the severe economic and energy problems Eastem European countries have experienctid 
problems Eastern European countries have experienced in the 1980's, it seems unlikely that all of these plants will materialize. In the wake of the Chernobyl accident, additional safety measures will undoubtedly be built into plants during the construction and planning stages. Currently, containment structures are being added to plants near completion in Bulgaria (Kosluduy 5 and 6). Lack of containment for reactors under construction (e.g., at Gdansk, Poland) has led to petitions and protests in COMECON countries that are not known for their public outspokenness. ${ }^{24}$

\section{The Impressive French Nuclear Power Industry}

France has developed a remarkable nuclear power industry. The increased use of electricity in all energy sectors has resulted in a growing energy independence that at the end of 1985 stood at 41\%. The percentage should continue to increase as conl used in power plants is displeced by nuclear fuels. About half of the coal used in France was imported in 1986. Four to five nuclear power plants are added to the electrical grid each year (Fig. 3). Table 9 summarizes the nuclear industry's contribution to electrical generation in France and the U.S. in 1986.

\section{The Keys to Success for French Nuclear Power}

Gaullist policies after World War II. By setting up the Commissariat a l'Energie Atomique (CEA) under the Prime Minister's control, and by encouraging every aspect of nuclear technology, both military and civilian nuclear energy programs got off to a good start. Under the Socialist government of Francois Mitterrand, attempts to "go slow" have met with limited success because of the good record of the nuclear program in the intervening years and the large popular support it now has.

Public support. Many factors contribute to the strong support nuclear energy enjoys in France. Probably the most important is the impressive record the industry has posted in the process of mitigating dependence on foreign energy sources. Cost overruns, delays, and accidents have not accompanied development. Installed cost per kilowatt in France is currently $\$ 1080$ (all inclusive) in 1986 dollars, compared to U.S. costs that are 2.5 to 3 times that amount. ${ }^{25}$ Apparently the movie "China Syndrome" was a flop in France. Critics of the nuclear power industry respond that the success of the program reflects the French political system that limits the role of public participation in the decision-making process. The French do not permit public hearings on whether a plant has been constructed safely. The only public input allowed is on site selection. Actually, cities compete for the plants, which provide thousands of jobs and substantial tax revenues. Until Chernobyl, the last serious opposition to nuclear power was in 1977 , although in 1982 a group of staunch oppositionists fired an anti-tank missile at the SuperPhenix breeder reactor, causing slight damage to the containment dome. A year after the Chernobyl accident, unofficial polls in France indicate opposition to nuclear plants had increased from 30 to 50\%." However, the French government has not taken steps to halt construction of reactors or to review its nuclear energy program. Another reason for the strong support is the pride the French take in succeeding in eliminating fossil fuels in

Table 9. Electrical generation in the U.S. and France (1986).

\begin{tabular}{lll}
\hline & France & U.S. \\
\hline Total electrical generation (bn kWh) & 358 & 2489 \\
Nuclear cortribution (bn kWh) & 252 & 434 \\
Percent nuclear & 70.0 & 17.4 \\
Electrical exports (bn kWh) & 25 & - \\
Installed nuclear capacity (GWe-net) & 40 & 86 \\
Number of operable power reactors & 45 & 109 \\
Annual nuclear capacity factor (\%) & 67.3 & 58.6 \\
\hline
\end{tabular}




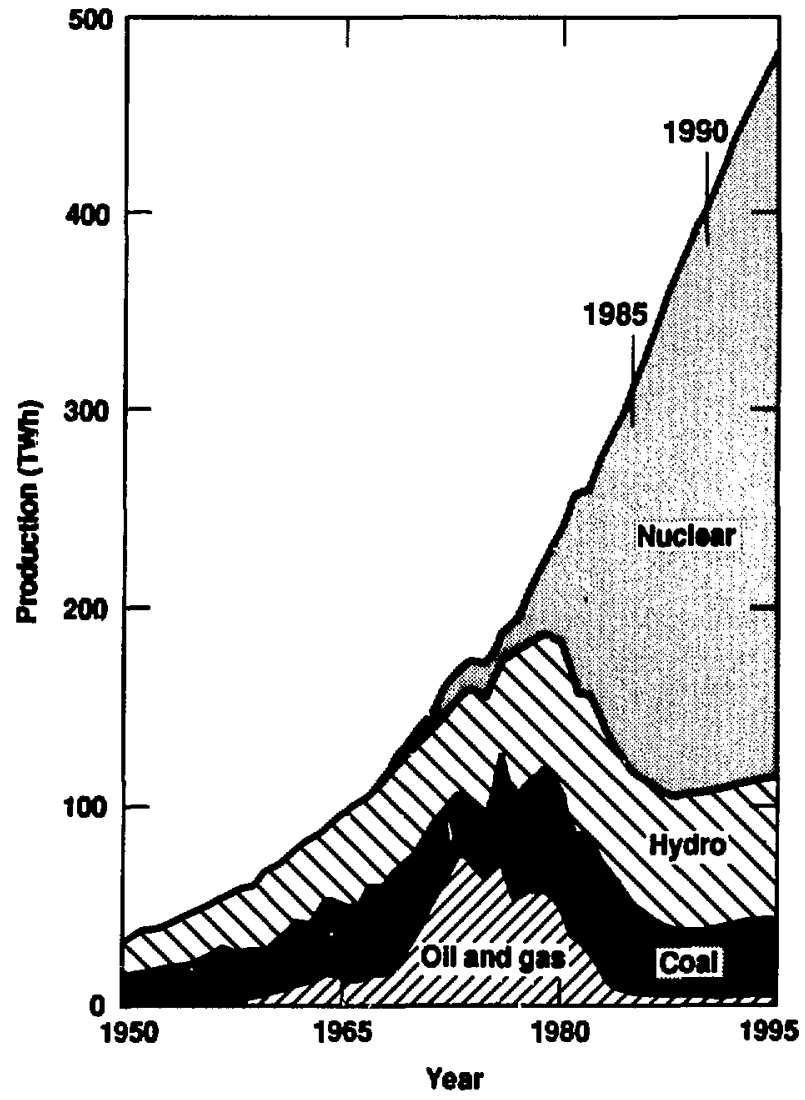

Figure 3. French electricity production by type of primary energy source. 2

power production, an area in wisich the U.S. has apparently failed.

Standardization of design and mass produc. tion of reactors. Apart from their early graphite gas-cooled reactors, the French have two standardized PWRs (thirty-two 900-MW units and six 1300MW units in operation with two 900-MW and sixteen 1300-MW units under construction). ${ }^{23}$ Within each series, specifications are identical and equipment suppliers receive orders from Framatome, the $85 \%$-government-owned reactor builder, to equip up to 16 units using the same procurement sources and subcontractors. Construction times, now about five years, have speeded up as builders have become familiar with the designs. Standardization has been possible because, in contrast to the U.S., France has only one national utility company in the nuclear business, Electricite de France (EdF), and it is a profit-making enterprise. The adversarial relatonship that exists between government and private utilities in the U.S. obviously has no counterpart in France.

High capacity factors. Annong countries with more than 20 nuclear power reactors, the capacity factor of French reactors $(67 \%)$ was exceeded only by that of Japanese reactors $(76 \%)$ in 1986 . High performance standards and capacity factors are possible because of the standardization of design and the uniforin training of reactor operators. To date, problems during operation have been minimal, although that reflects the average age of French reactors-about four years-compared to ten years in the older U.S. industry. 
Closed fuel cycle. France mines and enriches uranium for its reactors. In addition it has closed the fuel cycle by reprocessing spent-fuel rods, separating fission products, and extracting fissile uranium and plutonium. With the possible exception of one in the U.S.S.R., the reprocessing plant at La Hague, Normandy, is the largest in the world, having a capacity of 1600 tons per year in its two units. After a few years in temporary storage, the remaining long-lived isotopes and some transuranic elements are vitriffed and sent to long-term underground storage sites at Marcoule. The amount of vitrified waste is a few cubic feet per year per plant; additional repositories for highlevel waste are not expected to be needed for another ten years. France sells both its enrichment and fuel processing capabilities, but residual waste is now being returned to the country of origin.

In 1985, EdFdecided to recycle plutonium into its PWRs because entry of the plutonium-burning fast breeder into commercial service has been delayed by the slowdown of worldwide nuclear use. The La Hague reprocessing plant will produce about 8 toins of plutonium per year during the 1990 's. It will be added to the uranium fuel for 900-MW plants beginning at the end of 1987. EdF intends to use a mixture of $4.5 \%$ fissile plutonium in fuel assemblies containing depleted uranium, which until now has been discarded after uranium enrichment.

\section{The Super-Phenix Fast Breeder}

The Super-Phenix started to produce electricity in March 1986 and reached full power (1200 MW) in December 1986. A sodium leakin a subsidiary storage tank, discovered the following April, is likely to require costly repairs as well as a shutdown of the reactor. ${ }^{2}$ Nonetheless, the breeder is considered to be a technological success. It is owned by a consortium of utilities consisting of France's EdF (51\%), Italy's Ente Nazionale per 1'Energia Ellettrica (ENEL) (33\%), and a group from West Germany, Belgium, the Netherlands, and Great Britain (16\%). It cost an estimated $\mathbf{\$ 3 . 4 5}$ billion, three times original estimates in $1976,{ }^{30}$ and it represents an economic miscalculation because the cost of the electricity produced is twice that of the standard PWRs in France. Part of the problem is that the current uranium glut may extend into the next century and make plutonium a relatively expensive fuel. Because of power surpluses and, ironically, the improved performance of the PWRs, the French PWR and FBR programs are being pushed back, and it is unlikely that another breeder will be built in the near future.

Under a 1973 agreement signed with West Germany, the second fast breeder was to have been built by an international consortium in Germany; however, the Germans are in no hurry. The U.K. would like to host the third plant. Assuming these plants are ultimately built, the French will probably have to cope with the concerns of ecologists from these countries. In addition to 5.5 tons of plutonium and 83 tons of uranium-238, the SuperPhenix now contains $\mathbf{4 8 0 0}$ tons of molten sodium that pose formidable containment problems.

\section{Problems in the French Nuclear Power Industry}

By 1985, France's total nuclear installed capacity already exceeded the minimum electrical system daily load requirements, and more than 25 additional reactors were under construction. Early this year, EdF admitted that in 1990 it will have between two and four 1300-MW nuclear plants too many, even though some new plant orders were eliminated from planning in 1984 and 1985 . The reasons relate to the increased efficiency of the existing PWRs and a decline in French economic growth.

Electrical rates have been designed to promote the use of electricity in all end-use sectors; however, EdF is a profit-making utility, and rates do not constitute a subsidy. In addition, EdF has a large unit whose mission is to provide technical aid to industrial concerns interested in contversions and development of electrical processes that so far have not made in-roads into industrial sectors (e.g., radiation for drying, heat pumps, and high-powered variable-speed motors). EdF for the most part has closed its eyes to the mediocre thermodynamic yield of many electrical uses (e.g., electrical industrial boilers or conversion of central heating systems to electrical resistance heating units).

\section{Strategies to Deal with Over-Capacity}

Export power. Exports in 1986(Table9) constituted about $10 \%$ of France's nuclear output-25 billion kWh, up from 4 billion $k W h$ in 1982 . The goal is to export 50 billion $\mathrm{kWh}$ by 1990 , chiefly to the U.K., 
West Cermany, and other European countries. Rates currently charged to importers are anywhere from 24\% (U.K.) to 90\% (Italy) under local prices prevailing in those countries; yet the French still make a small profit. Whether exports can continue to increase is uncertain as bordering countries acquire additional nuclear capacity.

Load management. Nuclear plants are not suited to variable louds; demand increasingly fluctuates with seusonal and diumal temperature changes. In 1985, a one-iegree change in ambient temperature resulted in an $850-\mathrm{MW}$ increase in load; the same change is expected to increase the load to $1500 \mathrm{MW}$ by 1990 . The problem is being tackled in several ways: addition of pumped storage facilities, tariff restructuring to spread the load, and development of a reliable method to modulate reactor output. Framatome, the mostly stateowned reactor builder, has developed a system called Mode $G$, which allows a reactor to halve its power in 10 minutes and return to full power in another 10 minutes. Nonetheless, reactors that fol- low demand are not at optimum output, and their operation in that mode is less profitable than if they carried a permanent baseload.

Export reactor technology. The viability of the French nuclear complex is dependent on maintaining the health of Framatome. Overcapacity has resulted in a governmental decision to order only one new reactor per year for the next four years. Unless foreign orders are received, Framatome will have to cut its work force substantially. With a capacity to build six plants per year, France has been actively marketing Framatome's reactorbuilding capabilities abroad. To date, Framatome has sold plants only to South Koren and South Africa. The campaign to sell reactors abroad is aggressive, and the competition is stiff from West Germany's Kraftwerk Union (KWU) and the U.S.'s Westinghouse. In its effort to sell its know-how, Framatome's terms are saild to be "Give-aways." As Framatone can expect to replace France's existing reactors by the year 2000 , it need only campaign for foreign markets in the intervening years.

\section{Nuclear Power in West Germany}

Since the Chernobyl accident, tens of thousands of West Cermans have participated in sometimes violent demonstrations against nuclear power at the sites of recently licensed plants, at the construction site of a reprocessing plant, and at the site of a future storage facility for nuclear waste. The issue was brought to a head January 25, 1987, when federal elections determined that the current coalition of the Christian Democrats and the Christian Socialist Union would remain in power for another four years. The opposition parties (Social Democratic Party and the Green Party) are publicly against the development of nuclear power. The pro-nuclear stance of the current coalition was further bolstered in April 1987 by the elections in Hessen state, where a large part of the German nuclear industry is located. Concern over environmental issues, such as potential nuclear accidents and pollution of rivers and air, has strengthened support for the "Greens" at the expense of the Social Democrats rather than at the expense of the Christian Democrats.

The significance of continuing the existing governmental policies relevant to power produc- tion is that licensing and construction of nuclear reactors will continue at what has been a remarkable pace. At theend of 1986, installed capacity was 18.3 GWe, and another 4 GWe is scheduled to become operational between 1987 and 1990. The fast breeder at Kalkar (295 MWe), North Rhine Westfallen, is scheduled to begin operation in 1987. Its cost has escalated to the equivalent of $\$ 3.0 \mathrm{bil}-$

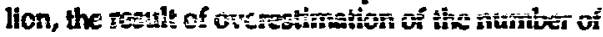
conventional nuclear reactors to be built and fueled and, hence, the underestimation of the future availability of uranium on world markets on the part of the International Atomic Energy Agency (IAEA) and Organization for Economic Cooperation and Development (OECD). Since 1970, OECD cut its projections of total OECD nuclear capacity for 1986 by two-thirds. Kalkar has been a particular target of the anti-nuclear movement in West Germany. Even if the current Bonn coalition government remains in power, it seems likely that Kalkar's operation will be delayed beyond 1987.

The only foreseeable major technical constraint to the continued operation and development of the nuclear power industry in West 
Table 10. Electrical generation in West Germany (1986).

Total electrical generation (bn kWh)

404

Nuclear generation (bn kWh)

121

Installed nuclear capacity (GWe-net)

18.3

Number of nuclear reactors

20

Annual nuclear capacity factor $(\%)$

78.8

Fuels used in power production (\%)

Coal

Nuclear

30

Oil and natural gas

Hydropower
12

5

Germany is the indication that the country already has surplus electrical generating capacity. Power plants fueled with fossil fuels supply $65 \%$ of the power, produced principally from domestic hard and brown coals (Table 10). The coal industry is heavily subsidized as a concession to the mining industry and under long-term contracts with the utilities. Environmental legislation requires that coal power stations be equipped with desulfurization plants. One-third of the plants have been converted, and others are at less than full capacity until conversion. When all plants are back in operation, presumably by the 1988 deadline for retrofiting, the surplus capacity will become troublesome unless demand increases more than the projected 2\% per year.

Under thesecircumstances, it is not surprising that the Bonn government, under pressure following the Chemobyl accident, commissioned studies on the feasibility of phasing out nuclear power. Both studies concluded that immediate shut-down

would not pose electrical supply problems, but wouid increase the price of electricity 1-3 pfenning/kWh. More important, the amount of pollution would increase appreciably, and additional strip mining of brown coal would devastate greatr: areas of the country. In the long view, imports of low-sulfur coal would be needed once coal stocks and the national coal reserve, now at an all-time high, were depleted. Coal exports, an important source of foreign currency, would cease. If other couniries also turned to coal for power production, world cnal demand and prices would rise, causing more than a modest increase in the current estimates of the electrical price increases associated with phasing out nuclear poiver.

Like Framatome, its German counterpart KWU has been looking to foreign sales to maintain its business. The company is the fourth largest nuclear plant builder in the free world after Westinghouse and General Electric (GE) in the U.S. and Framatome. KWU has not sold a nuclear plant since 1982 but has survived filling back orders in Germany, Spain, Argentina, and Brazil."11 In addition, since Chernobyl, Dutch and Finnish officials postponed their planned purchases from KWU for several years.

Adding fuel to the anti-nuclear movement is the construction of the Wackersdorf nuclear reprocessing plant in Bavaria, the site of the destructive demonstrations in 1985-86. In response to Austrian protests, the second license dealing with construction of nuciear components will not be granted until 1988 at the earliest. Perhaps not fortuitously, the year of planned completion of the plant (1995) coincides with the expiration of the Treaty for Non-Proliferation of Nuclear Weapons and the ban on production and ownership of nuclear weapons in West Germany.

\section{The U.K.'s Aging Reactors: A Mediocre Record but Indispensable}

The backbone of the U.K. nuclear industry is a series of 18 Magnoxes built in the early 1950's and 60 s. They supplied approximately $75 \%$ of the U.K.'s nuclear-generated electricity in 1985-86. The Magnox is a gas-cooled, graphite-moderated British design that has undergone extensive scrutiny since the Chernobyl accident. Reactors at the Berkeley and Bradwell sites, like Chernobyl, lack secondary containment structures. No other country except the U.S.S.R. relies so heavily on such an old group of reactors. There is some discussion by the utilities that own the Magnoxes to extend their operating lives to 30 or 35 years. However, proposals to phase out nuclear power in Great Britain usually target the Magnoxes as the first to be retired.

Construction of the Magnoxes was followed by construction of a series of advanced gas reactors (AGR) in the 1970's and 80's. Between 1970 and 1980 , only one additional reactor order was placed. 
As a group, the U.K.'s reactors are associated with sub-average load factors (Table 11). The average lifetime load factor for U.K. reactors as a group is $\mathbf{5 4 \%}$, as of September 1986. For comparison, lifetime load factors are between 71 and $78 \%$ in Finland, Belgium, West Germany, and Switzerland. A new PWR design based on a Westinghouse license was the subject of an epic inquiry started in 1983. Early in 1987, the PWR planned for Sellafield was endorsed on the basis of safety and economics by Sir Frank Layfield, who conducted the hearings. ${ }^{32}$ Although the report did not deal with other PWRs of the same design, the Central Electricity Boand has now started to plan for Hinkley C, another PWR, in southwest England," The Layfield report may be the death knell of the AGRs in Great Britain.

Sellafield, previously called Windscale, has been the site of numerous $(500)$ accidents and near diasters, starting in 1957 with a graphite fire and near core melt down in a plutonium production reactor. The Windscale accident, which killed 39 people, is the second most serious accident after Chernobyl. A combination of accidents and deliberate discharges of radionctive wastes in to the Irish Sea over the years has made the sea the most radioactive body of water in the world.

Sellafield is also the site of the world's largest uranium reprocessing plant. It currently processes spent Magnox fuel (natural uranium) and is a temporary repository of almost all nuclear waste that has been generated in the U.K. over the past 30 years. The plant is old but would still have to run for another decade if all Magnoxes were retired today and their fuel reprocessed. In order to "sell" Sellafield, British Nuclear Fuels, owner of the plant, has opened the plant to tourists; some 65,000 people visited the plant in $1986 .{ }^{34}$

The site also stores oxide fuels from the U.K.'s advanced gas-cooled reactors while an oxidereprocessing plant and waste handling facility is being built. About one-third of the spent fuel that will be processed in the new plant will come from the U.K. and the remainder from Japan (39\%), West Germany (14\%), and other European countries. ${ }^{16}$ As insurance against delays in startup and emergencles after the plant opens, U.K. utilities are financing dry buffer storage capable of storing spent fuel from one year's operation of the U.K.'s AGRs.

The Chernobyl accident prompted several studies on the fensibility of phasing out nuclear power in the U.K. At the end of 1986, the Economics Department of Reading University, on behalf of a group representing 70 local authorities in the coal fields, issued a report concluding that nine Magnox reactors could be closed over the next three years with minimal loss and cost.*

Such a painless phase-out is predicted because of the central utilities' acknowledged current excess generating capacity. Historically, excess capacity has been purposely built into the system to hedge against various exigencies, such as abnormally cold wintere To close the remainder of the country's reactors by the end of the

Table 11. Electrical generation in West Germany and U.K. (1986).

\section{Weat Germany UaK.}

Total electrical generation (bn kWh)

404

302

Nuclear contribution (bn $k W h$ )

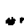

121

59

Total electrical generating capacity (GWe)

90 (1985)

81 (1985)

Instalied nuclear capacity (GWe)

18

12

Number of operable power reactors

20

38

Annual nuclear capacity factor (\%)

79

56

Fuels used in power production $(\%)$

Coal

Nuclear

Oil and natural gas

Hydropower
12

61 (1985)

20

17 (1985)

Includes eelf-generntion by non-utilitieo. 
century would result in the need to expand coal mining in the U.K. and ultimately import coal. The consequent increase in the price of electricity is estimated to be $10 \%$. In addition, such a plan would call for an immediate start of plans and construction of new coal-fired power plants. A 1986 study of phasing out nuclear reactors by the U.K. chapter of Green Peace essentially came to the same conclusions.

Perhaps the strongest argument against retir- ing the U.K.'s nuclear reactors is that the country would be at the mercy of the coal mining industry for its electrical power. Threats of a coal strike and subsequent power cuts would hold the country to ransom. Not all members of the Labour Party are likely to concur with their party's officiai policy of abandoning nuclear power in view of such consequences. Few have forgotten the two coal miners' strikes since 1973 and their impact upon the country's economy.

\section{The Swedish Dilemma: Abolishing Nuclear Reactors}

In March 1980, Sweden voted by referendum to phase out all nuclear reactors in the country by 2010. The vote was strongly influenced by the Three Mile Island Accident in 1979. However, proponents argued that they were against nuclear power not only because of potential accidents; they were also concemed with nuclear waste and environmental and nuclear weapons issues. Until Chernobyl, anti-nuclear sentiment showed some signs of waning; after Chernobyl, however, polls indicated that only $26 \%$ of thosequestioned would vote in favor of nuclear power. At that point, the government began looking into the possibility of phasing out nuclear power during the next decade.

To put the situation into perspective and to assess the challenge of a phase-out by 2010, much less by 1997, one must look at Sweden's unusual energy picture:

- Sweden has some of the lowest electrical costs in the world because of the combination of hydropower (44\%) and nuclear power (51\%) (see Table 12).
- Elce arical consumption has been increasing an average of $10 \%$ per year in the 1980 's.

- Remaining untapped hydropower is substantial, but last year the parliament voted full protection for four remaining major rivers in response to a vigorous environmental movement.

- Half of Sweden's nuclear power plants (a total of $9.6 \mathrm{GWe}$ ) became operational within the last five years, and their retirement before the norma! 35-year lifetime represents a substantial firancial luss to the country.

A Swedish group of experts, commissionea' after the Chernobyl incident to evaluate the possibility of eliminating nuclear power tefore 2010, reported that immediate closure would have dire consequences for thecountry's economy." Closure over the 1987-97 period would result in doubling of electrical prices, and all end-use sectors would be impacted. For example, the steel, pulp, and paper industries would lose profitability, and the residential sector-in the process of switching to oil heating-would be forced to make substantial invest-

Table 12. Electrical generation in Swecien and Switzerland (1986).

\begin{tabular}{lll}
\hline & Sweden & Switzerland \\
\hline Total electrical generation (bn kWh) & 137.6 & 57.3 \\
Exports/(imports) (bn kWh) & 4.6 & 7.8 \\
Nuclear contribution (bn kWh) & 70.3 & 22.5 \\
Percent nuclear generation (\%) & 51 & 39 \\
Percent hydroelectric (\%) & 44 & 59 \\
Installed nuclear capacity (GWe-net) & 9.6 & 2.9 \\
Number of operable power reactors & 12 & 5 \\
Annual nuclear capacity factor (\%) & 80.4 & 82.9 \\
\hline
\end{tabular}


ments and raise pollution levels. Closure by 2005 would be the gentlest solution; however, by any measure, substitution of fossil fuel-burning power plants for the nuclear plants with attendant high capital and operating costs woukd affect the country's economy, environment, and standard of living, currently one of the highest in the world. There is a forlorn hope that alternative forms of energy-wind and solar-plus conservation will mitigate the transition.

Assuming that the government does not accelerate the decommission of the nation's reactors, what are the prosible fuel substitutes? Imported coal or domestic peat are two. Imported natural gas from either Denmark or Norway is another. Some gas is already imported to southem Sweden from Denmark, and Norway would like a market for its surpiss gas from its fields in the North Sea. Disadvantages include the cost of pipelines added to the cost of new power plant construction. Far more important is the fact that the North Sea gas is not limitless; oil production there is expected to peak in the 1990's. Although gas produced to date has been reinjected for lack of pipelines to markets, it ultimately will be depleted once it is tapped for
European customers. In hope of developing domestic sources of natural gas, the Swedes in 1986 embarked on an exploratory drilling program in the crystalline basement, which is not the usual gas habitat. So far, the results have not been encouraging.

An observer woul 4 have to conclude that Sweden is currently determined to eliminate its 12 reactors at any cost. The first reactors to be closed, at Danish insistance, almost certainly would be the two at Barsebaeck in southern Sweden near Copenhagen. Southern Sweden has no substantial resources, and imported coll-burning generating plants may well be located there. Two are in the planning stage at Oxelosund and Malmo; however, the generating capacity of the two plants probably will not be equal to that of the twin reactors at Barsebaeck (1200 MW)." It appears that phasing out nuclear power in Sweden could be managed with sacrifice by the designated year, assuming that the world polltical scene remains calm. In a world with uncertain imported fupl "spplies, the Swedes would almost certainly take a second look at their plan, a plan that could result in disastrous consequences to their industry and society.

\section{Finland's Reactors Have an Excellent Record}

If Sweden decommissions its nuclear reactors as planned, Finland will be the only country in Scandanavia with nuclear power. Although Chernobyl had a dynamic impact on opinion in neighboring Finland, it was notsonegativeas to bring the issue into the political arena or set the stage for phasing out nuclear power. Finland depends heavily on nuclear power (40\%) to generate electricity (Table 13).

Four plants are currently operating. Two are PWRs of Soviet manufacture and two are BWRs purchased from Sweden. Collectively they had a capacity factor of $89 \%$ in 1986 and $90 \%$ in 1985, which was not surpassed by any other country. Finland relies on the U.S.S.R. for much of its energy imports (i.e., in 1985 all of its natural gas, 73\% of crude oil, and 75\% of electricity). ${ }^{30}$ Thus, it is not surprising that is turned to the east for reactor expertise. Finland is the only non-Soviet bloc country to use Soviet-designed reactors. A clear advantage is that the Soviet Union is responsibile for the entire fuel cycle. Such is not the case with the two reactors purchased from Sweden; responsibility for enrichment, fabrication, and disposal of spent fuel rests with the Finns.

Installation of the Soviet PWRs at Loviisa, Finland was a joint effort. The steam generators are installed horizontally, because space, at least in the U.S.S.R., is not at a premium. They have been particulariy trouble-free; and their high capacity factors, both in the low nineties, have been attributed to various aspects of the steam generator design. In

Table 13. Electrical generation in Finland (1986).

Tatal electrical generation (bn kWh) 48.8

Electrical imports (U.S.S.R. and Sweden) (bnkWh)

Nuclear contribution (bn kWh)

Percent nuclear generation

Installed generating capacity (1985)(GWe)

Installed nuclear capacity (GWe-net)

Number of operable power reactors

Annual nuclear capacity factor (\%) 
contrast to Soviet installations, the Finnish reactors have containment structures built to U.S. Nuclear Regulatory Commission specifications. The Loviisa reactors are built on an island just offshore and use once-through cooling water from the Gulf of Finland.

Finnish electrical demand has been increasing about $2.5 \%$ annually in normal years and is anticpated to increase by slightly less in the next decade. Soon Finland will need additional generating capacity or will have to increase power imports, which were $9 \%$ of total consumption in 1986. In the wake of Chernobyl, the government has decided not to buy their fifth reactor from the U.S.S.R. as originally planned. Instead, Finland, like many other European countries, is turning to coal and is planning to build two 500-MWe coal-burning plants and two small peat-fired plantsusing indigenous peat." Even if the Finns should reverse their decision not to build another nuclear plant, only a small possibility exists for it to be operational in this century.

\section{Switzerland's Debate Over Nuclear Energy}

It is ironic that both Switzerland and Sweden have contemplated shutting down their nuclear reactors. It is ironic because both countries:

- Have reactors with good safety records and some of the highest capacity factors in the world (Table 12).

- Rely heavily on nuclear energy for electrical power (see Table 12).

- Have some of the lowest electrical costs and the highest standards of living in the world.

- Record steady growth of electrical consumption-almost 10\% annually in Sweden and 4-5\% in recent years in Switzerland. natives.

- Have virtually no indigenous energy alter-

Since 1979, Switzerland has had a series of national and local referenda over the future of nuclear power. Then the electorate narrowly defeated a proposal that decisions to bulld future nuclear reactors be made by democratic means, i.e., by referendum.

In 1981, two referenda were held to decide whether any adciitional nuclear plants would be built and whether the country would opt for a safe, efficient and environmentally sound energy supply. Both were defeated by 55 and $54 \%$ of the electorate, respectively, al though failure of the second was remarkable in view of its general appeai. The wording of that proposal was shrewd and difficult to oppose. It prescribed a spectrum of conservation and efficiency measures, including prohibition of electrical heating as well as subsidies and energy taxes to promote its objectives. It decreed that no conventional or thermal power plant could be constructed larger than $35 \mathrm{MW}$. Thus, without explicitly saying so, the proposal would have pro- hibited construction of four nuclear plants that were in the planning stage. Pro-nuclear groups pointed out that the growth in electrical consumption during the 1980's compounded the cifficulty of reaching the stated objectives; however, the proposal probably was defeated by the high energy taxes-estimated to be 50-60\%-necessary to support the measure because the Swiss are notoriously adverse to taxes of any kind.

In all of these referenda, the Gurman cantons, except for the two Basel cantons, sup ported nuclear energy; the Italian and predominantly French cantons tended to reject it. In the interim, the Germen cantons of Bern and Zurich reversed their positionsas has the international canton of Geneva.

In the wake of the Chernobyl accident (April 26, 1986), two more initiatives to curtail nuclear power surfaced. One launched by the Socialist Party called for abundonment of nuclear power and the promotion of altermatives, and the other called for an immediate moratorium on building nuclear plants for ten years. The latter initiative now has more than the 100,000 signatures required for organizing a national referendum. After vigorous debate on whether to limit or abandon the nuclear option, the Swiss upper house decided to make no ruling until a study of the economical and societal consequences of such a move was completed in 1987. The lower house defeated motions to decommission existing nuclear plants as soon as possible and to revoke thegeneral authorization for the sixth, yet-to-be built ruclear plant.

Assuming that the nuclear issue is put to a vote again in 1987, there is a good chance that the past narrow margins favoring nuclear energy will disappear. It is possible that the four planned 
nuclear plants (Kaiseraugst, Graben, Verbois, and Inwil) will be deferred. Two strong arguments in favor of deferment are (1) Switzerland currently is a net exporter of electricity, and (2) natural gas imports on long term contracts from the North Sea, the Netherlands, and the Soviet Union are expected to increase substantially in the next few years. It is conjectural whether or not the practical Swiss will follow the Swedish lead and vote to phase out their existing nuclear plants, but it seems unlikely, particularly in view of the on-going development of district heating using waste heat from the reactors. The Swiss take great pride in those projects and have good regional support for them.

\section{Nuclear Energy in Belgium and the Netherlands: A Study in Contrasts}

Nelghbors Belgium and the Netherlands have come to gripe with theirenergy needs in very different ways. Their contrasting paths have resulted from the largeindigenous reserves of natural gas in the waters offshone of the Netherlands and the absence of equivalent supplies in Belgium.

The Netheriands is the fourth largest gas producer in the world; its production is exceeded only by the U.S.S.R., U.S., and Canada. Abundant naturil gas has led to a strong economy and a high standard of living. Almost half of the gas is exported. Becnuse gas is used as a fuel for electrical power production, it is not surprising that the country has moved slowly tuisard nuclear power (Table 14). In fact, in view of the large amount of natural gas available, it is remarkable the Dukh have even two nuclear plants, and that a Dutch utility group has a vested interest in the SNR-300 breeder reactor at Kalkar, West Germany. Even before Chernobyl, the Dutch people when polled indicated that they were adverse to the construction of any additional nuclear power plants in the country. Almost certainly upon retirement of the two existing nuclear plants, probably near the hurn of the century, the Netheriands will replace them with plants fired by fossil fuels or alternatively tum to France for additional imports of electricity. Already the Netherlands' economics minister has approved plans to build two new $600-\mathrm{MW}$ conlfired plants in the early 1990 's to replace the two nuclear plants that were approved but later halted after the Chernobyl accident." Future use of natural gas for power production will be limited by the finite reserve base as well as by increasing natural gas commitments to district heating and long-term export contracts, principally to West Germany and France.

Compared to Belgium, only two European countries, Ireland and Denmark, are more poorly endowed with ritural resources. Belgium has no oil, very little natural gas, and only meager coal reserves. In contrast to other European countriessuch as Finland, Sweden, Austria and Portugal, which also lack indigenous hydrocarbons in notable quantities-Belgium has a very small hydroelectric potentivl. For the past few decades, Belgium has depended heavily on imported fuels while it muintained a highenergy consumption per capita. In 1984, use exceeded that of Sweden, Swiberland, France, U.K., Jaf ani, and others."

Forced reliance on imported fuels led Belgium to turn io nuclear power genesation. Currently, it is

Table 14. Electrical generation in the Netherlands and Belgium (1986).

\begin{tabular}{lcc}
\hline & Netherlands & Belgium \\
\hline Total electrical generation (bn $k$ Wh) & 67.2 & 58.6 \\
Nuclear contribution (bn kWh) & 4.24 & 39.6 \\
Percent nuclear generation & 6.3 & 67.5 \\
Installed nuclear capacity (GWe-net) & 0.51 & 5.48 \\
Number of operable power reactors & 2 & 8 \\
Number of reactors under construction & 0 & 0 \\
Annual nuclear capacity factor ( 5 ) & 83.2 & 76.2 \\
\hline
\end{tabular}


second only to France in the extent of its dependence on nuclear reactors for power production (Table 14). Belgium has eight operating power reactors, the last of which became operational in 1985. A ninth 1.4-GWe(net) reactor was planned, but authorization of the construction has been delayed by government offictals who would iike to await the outcome of a debate on the consequences of Chernobyl before giving an okay on the project.

Together with the Netherlands, the U.K., and Germany, Belgium is a member of the utility consortium that is backing the fast breeder reactor at Kalkar, Germany.

\section{Nuclear Energy in Italy}

Despite Italy's heavy reliance on oll and gas for power production, nuclear energy has not made headway in the country. Currently, Italy has a total of 1.3 MWe of installed nuclear capacity at three plants, two of which are small and near the end of their useful lives (Table 15). The National Energy Pin, adopted in 1981, cnlled for the construction of $12 \mathrm{GWe}$ in new nuclear and $12 \mathrm{GWe}$ in coul-fired plants. Yet, because of local opposition and site selection problems, only two nuclear plants are under construction (Aito Lazio), and only one additional plant site has been chosen (Trino Vercellese) and is in the early stages of planning and construction. TheI talian Electricity Board (ENEL) has cited" conflicting local, state, and national interests and the lack of federal cross-cutting laws as the reasons for the slowness in implementing the national energy plan. The nuclear plant at Trino Vercellese in the Piedmont was given the goahead by regional authorities only after lengthy negotiations, dissemination of information about regional benefits and trade-offs, i.e., investment in local infrastructure and services by ENEL.

Chernobyl has had a profound influence on opinion in Italy: three cut of four Italians are firmly opposed to installation of nuclear power plants." Half a million signatures have guaranteed a referendum on the subject sometime in 1987. Referendum in Italy can only abrogate or amend existing Laws. Thus, the isaues are whether or not financial subsidies can be given to regional authorities where plants are to be localed, whether the interministerial committee for economic planning that wrote the National Energy Plan can decide where new power plants are to be located, and, listly, whether ENEL can engage in joint ventures with foreign corporations. The last issue would affect ENEL's participation in the Super-Phenix fast breeder reactor project in France, from which the Italians are fust beginning to get much-needed one-third of the electrical output.

Table 15. Electrical generation in Italy and Spain (1986)."

\begin{tabular}{lll}
\hline & Italy & Spain \\
\hline Total electric generation (bn kWh) & 192 & 123 \\
Nuclear contribution (bn kWh) & 8.7 & 37.5 \\
Importa/(Exports) (bn kWh) & 22.1 & $(1.3)$ \\
Nuclear generation (\%) & 4.5 & 30.5 \\
Installed nuclear capacity (GWe net) & $1.3^{2}$ & 5.6 \\
Number of operable power reactors & 3 & 8 \\
Number of reactors under construction & 4 & 26 \\
Annual nuclear capacity factor (\%) & 74.4 & 75 \\
\hline
\end{tabular}

- Mue an equity in France's Super-Fhenix breeder resctor that reached full power December $9,1905$.

b An additional five in varlons etass of conetruction are mothballed. 


\section{Nuclear Energy in Spain}

In 1983, the Spanish government announced plans to reduce the nuclear enerating capacity in the 1983-1992 plan from 12.5 GWe to 7.5 GWe. Current capacity is 5.6GWe(Table 15). The reasons cited were expected overcapmcity and capital considerations. In view of the weakness of the pesata, an over-ambitious nuclear program could havehad severeimpact on thenation's financial heal th. Since 1983, at least one utility in Spain (Fesca) has attributed its near financial collapse to loans it took out for nuclear plants."

At the time of the 1983 decision, seven plants were under construction; five have been mothballed since then. The government compensated the state's private utilities for money spent or committed to the five plants by seiting up a special fund partially fed by a $6 \%$ increase in electricity rates. The utility had hoped that construction on at least one of the mothballed plants would be resumed when demand increased faster than the government's projections of 3.3\% per year to 1992. That has not occurred to date, and the predicted nead for only 7.5-GWe installed nuclear capacity now appears realistic."

\section{Nuclear Energy in Yugoslavia}

Yugoslavia's overall economic development is tied to the development of additional electrical genurating power during the next 15 years." Currently, hydroelectric power and coul-fired plants account for about $90 \%$ of installed capecity (see Tab'e 16). Because only a small amount of hydropower can be added to meet future needs, increased generating capacity is expected to be coal-fired with indigenous fuels. Two new nuclear plants are in the talking stage; however, limitations on Yugoslavia's? ability to find loreign financing may decide whetker or not they proceed beyond that. One Westinghouse PWR was operating in the country as of 1983, and none is under construction.

Table 16. Electrical generation in Yugcalavia (1986).

\begin{tabular}{ll}
\hline Total electrical generation (bn kWh) & $70^{\circ}$ \\
Nuclear contribution (zn kWh) & 3.8 \\
Nuclear generation (\%) & 5.4 \\
Installed xuclear capacity (GWe-net) & 0.62 \\
Annual nuclear capucity factor (\%) & 69.2 \\
\hline
\end{tabular}

- Caleriatad. 


\section{Non-Nuclear European Countries: \\ Norway, Austria, Denmark, Portugal, Greece, and Ireland}

To the question, "What do the six non-nuclear European countries have in common?" the answer is "very little." They are not anti-nuclear as a group, although the Chernobyl accident had a profound influence on opinion in all six countries. Each country has approached electrical generation from a slightly different point of view, dictated by its unique indigenous resources (see Table 17 ). None has fudged that construction of nuclear resctors was the alternative to what had been, in many instances, heavy dependence on imported oil for production of power.

Norway's electrical consumption is similar to Sweden's; however, Norway's abundant hydropower is more than able to supply the country's growing demand. Nuclear power has never been serlously considered for electrical generation, particularly in the light of its largely unmarketed North Sen natural gas, which could be used if demand surpasses hydropower's existing capacity. Norway does have, however, a small (20MWh) heavy-water research reactor at Halden.

Austria, too, depends heavily on hydropower for the generation of electricity. Electrical demand has risen sharply in recent years, which has eroded the amount of power exported. A proposed hydro- electric power plant at Hainburg has been postponed, if not shelved, by environmental opposition to the destruction of one of Europe's last primeval forests. Despite what appear to be impending power shortages, the Zwentendorf BWR nuclear plant ( $700 \mathrm{MW}$ ) completed in 1978 is scheduled to be dismantled over the next seven years. The plant was never commissioned because of a referendum decision (31.6\% against, $31 \%$ for, and 37.4\% abstaining). Until Chemobyl, the utility that owned Zwentendorf hoped for a reversal in opinion on the subject of nuclear power. The cost of construction and maintenance in the intervening years has been on the order of 10 billion Austrian shillings. A study of possible conversion of the plant to coal concludea that conversion would be more expensive than building a new coal-fired plant.

The Chernobylincident tiggered an Austrian crusade against its nuclear neighbors. The small country is surrounded by 32 nuclear plants, some of them only tens of miles from its borders, in West Germany, Switzerland, Czechoslovakia, and Hungary. A special crusade target in 1987 is the planned nuclear reprocessing plant at Wackersdorf, Bavaria.

Table 17. Electrical generation in six non-nuclear European countries (1986 data unless indicated otherwise).

\begin{tabular}{lcclc}
\hline Country & $\begin{array}{c}\text { Installed } \\
\text { capacity } \\
\text { (GWe) }\end{array}$ & $\begin{array}{c}\text { Electrical } \\
\text { production } \\
\text { (bn kWh) }\end{array}$ & \multicolumn{1}{c}{$\begin{array}{c}\text { Principal } \\
\text { fuel }\end{array}$} & $\begin{array}{c}\text { Electric } \\
\text { Importa(+) } \\
\text { Exports(-) }\end{array}$ \\
\hline Ireland & $3.25(1985)$ & 12.6 & $\begin{array}{l}\text { Domestic nat. gas } \\
(54 \%) \text { and peat (20\%) }\end{array}$ & $(0)$ \\
Portugal & $5.4(1983)$ & 20.1 & Hydropower (42\%) & $(+)$ \\
Greect & 7.0 & 27.4 & $\begin{array}{l}\text { Womestic lignite } \\
(65.5 \%)\end{array}$ & $(+)$ \\
Denmark & $7.7(1985)$ & 50.0 & $\begin{array}{l}\text { Imported coal (80\%) } \\
\text { Hydropower (72\%) }\end{array}$ & $(+)$ \\
Norway & $14.7(1983)$ & 44.1 & Hydropower (99\%) & $(-)$ \\
\hline
\end{tabular}

- Incindes lowes. 
Denmark's resources are limited: hydropower constitutes only $0.3 \%$ of its electrical production, it uses its North Sea gas for non-electrical uses and export, and it is a net importer of power. Yet, Denmark has decided against nuclear power although similarly situated countries with electrical demand of the same magnitude, e.g., Hungary, have opted to build nuclear plants. Instead, Denmark has chosen to convert existing oil-fired plants and build new plants fueled by imported coal. South Africa and Poland are its main coal suppliers. Within ten years, Denmark's dependency on oil for all energy uses dropped from $95 \%$ to less than $50 \%$. There is little likelihood that nuclear plants will be built in the foreseenble future. The Chernobyl accident brought renewed demands of the Swedes to shut down the two-unit Barsebaeck nuclear power plant in Southern Sweden, some $20 \mathrm{~km}$ from Copenhagen, before the decreed 2010 dismantling date in Sweden. Because southern Sweden depends almost exclusively on the Barsebaeck units for power and because the units are both approximately ten years old, Sweden has been reluctant to agree to immediate dismantling. It seems to be immaterial to the Danes that their power imports, some $7 \%$ of total consumption which comes chiefly from Barsebaeck nuclear plants, would most likely cease.
In Portugal, Greece, and Ireland, the size of electrical demand (Table 17) and limited financial assel save precluded the pursuit of thenuclearoption with any fervor. Nonetheless, Portugal has raised the nuclear question since it has sizable uranium resources. It is currently studying Canada's CANDU system, which is attractive because it uses natural uranium, thereby obviating costs of obtaining enriched uranium.

In Greece, the process of converting oll-fired plants to coal continues. Oll generated $20 \%$ of the power in 1985. The modification of several ligniteburning plants to burn coul-lignite mixtures has increased electrical output substantially. Greece hopes to import natural gas from the U.S.S.R. and liquified natural gas from Algeria in the next decade. There is some concern that a recent slowdown in the country's econoinic activity in recent years will result in overcapacity in 1987.

Ireland converted its oil-fired generating units to dual firing in order to take advantage of its domestic natural gas supplies. It also built its first $300-\mathrm{MW}$ coal-fired ylant, and two more are in the offing. It has canceled plans for a $650-\mathrm{MW}$ PWR because such a large power source would decrease rather than increase energy security. Future nuclear energy in Ireland appears to be only a remote possibility.

\section{Nuclear Power in Japan}

Japan's primary energy supply comes overwhelmingly from foreign sources ( $82 \%$ 'n fiscal year 1984).51 The principal import is Middle Eastem oil, which fuels the industrial and transportation end-use sectors of the country. It is also the chief fuel for electrical power generation, which is consumed predominantly by Japanese industry. Thus, it should be no surprise that Japan has made herculean efforts to promote nuclear power. By 1975, installed nuclear capacity exceeded that of the Soviet Union (Fig. 1), although that lead was lost in 1981. Nonetheless, because of high capacity factors, the total amount of power generated with nuclear reactors in 1986 remained on a par with that of the U.S.S.R.

Japan is fourth in world nuclear power generation behind the U.S., France, and the U.S.S.R. (Table 18). Like France, Japan's record is impressive. Five of Japan's 34 reactors were anong the world's top ten performers in 1986.52 The U.S. placed two of its 100 hundred reactors on the list. Capital costs associated with recently constructed nuclear reactors in Japan have been reduced by shortened construction times. Two units that became operational in 1985(Takahama 3 and 4) were built in $\mathbf{4} 3$ and 59 months, respectively." The best U.S. construction times are a year or more longer, and the U.S. average is about five years longer. Even so, Japanese reactor construction costs are among the highest in the world. Two advanced BWRs were ordered from GE in 1987 (Kashiwazaki-Kariwa 6 and 7-1356 MWe each) and are expected to cost $\$ 5$ billion, or approximately $\mathbf{\$ 1 8 5 0}$ per installed kilowatt. ${ }^{53}$ The order represents the first new one for GE since 1975. The majority of Japan's reactors were designed and built by Japanese companies. The technology was introduced into Japan under license from GE and Westinghouse. To develop an indigenous reactor, a prototype $148-\mathrm{MW}$ advanced thermal reactor 
Table 18. Electrical generation in Japan (1986).

\begin{tabular}{lllll}
\hline & Japan & U.S.S.R. & U.S. & France \\
\hline Total electric generation (bn $\mathrm{kWh}$ ) & $674^{\mathrm{a}}$ & $1560^{\mathrm{a}}$ & 2489 & 358 \\
Nuclear contribution (bn $\mathrm{kWh}$ ) & 165 & $148^{\mathrm{a}}$ & 434 & 252 \\
Nuclear generation (\%) & 25 & $10-11^{\mathrm{a}}$ & 17.4 & 70 \\
Installed nuclear capacity (GWe-net) & 24 & $30^{\mathrm{b}}$ & 86 & 40 \\
Number of operable power reactors & 34 & 55 & 100 & 45 \\
Number of reactors under construction & 11 & 37 & 25 & 17 \\
Annual nuclear capacity factor (\$) & 76.2 & $\mathbf{n a 0 ^ { c }}$ & 58.6 & 67.3 \\
\hline
\end{tabular}

"Eetimated; U.S.S.R. extmate bued on nine monthe, Ises data."

Includes Chemobyl 1, 2, and 3 but not 4.

e Not svallible.

(ATR) became operational in 1979. It is a lightwater-cooled, heavy-water-moderated reactor that uses a mixed plutonium-enriched uranium oxide fuel. It is specifically designed to utilize plutonium recovered from reprocessed fuel rods. A commercial reactor to be operational by 1995 is in the planning stage.

Japan relies on the U.S. for approximately $90 \%$ of its uraniumenrichment requirements and sends its spent fuel for reprocessing to Sellafield, U.K., and to Cap La Hauge, France. However, the government built a pilot reprocessing plant in 1977 at Tokai..$^{\mathrm{A}}$ At Rokkashomura, Honshu Island, $\$ 4.5$ billion has been approved for a nuclear complex that will enrich fuel using the centrifuge method and reprocess spent fuel. The Rokkashomura unit will supply roughly one-sixth of Japan's needs by the year 2000 . When operational, by 1995, the reprocessing plant will yield 5-6 tons plutonium annually.

Early in 1986, Japan finished its uraniumfrom-seawater pilot plant at Nio, Shikoku Island. Approximately $1800 \mathrm{~m}^{3} / \mathrm{h}$ of seawater (3 ppb uranium) will be passed through absorbers (hydrous titanium oxide) and desorbers (sodium bicarbonate and conventional ion exchange columns). The yield is expected to be $10 \mathrm{~kg}$ of $\mathrm{U}_{3} \mathrm{O}_{3}$ per year. To put ihis figure in perspective, this means annual consumption in the 1983-1991 period will be on the order of $4500-5500 \mathrm{~kg}$. assuming reactor capacity of $33 \mathrm{GWe}$. Cost considerations will dictate whether or not the process will ever expand to compete with conventional imported uranium sources. Currently, Japanese power utilities have purchased an oversupply of uranium on long-term contracts, a decision based on over-optimistic forecasts of future requirements. Suppliers are chiefly from Canada, kustralia, and South Africa.

The prototype Monju fast breeder is scheduled to "go critical" in October 1992, a delay of 18 months from the original date. Thedelay of the 280 MWe prototypehas been attributed to escalation of cost estimates. Under an agreement between the U.S. DOE and the Power Reactor and Nuclear Fuel Development of Japan, which is building Monju, some components from the canceled U.S. Clinch River Breeder, valued at $\$ 1.1$ million, will be supplied at no cost in return for operating and testing data. ${ }^{35}$ 


\section{The Nuclear Option in the Far East: Taiwan, Republic of Korea, the Philippines, and China}

Asian nations pursuing the nuclearoption for power production have been courted by the world's principal nuclear reactor manufacturers for a decade or more. Except for modest amountsof hydropower, Taiwan, the Republic of Korea, and the Philippines are without appreciable domestic resources for electrical power generation. However, Korea does have some coal, and the Philippines have exploited geothermal resources for some years. Of these countries, Taiwan has moved the most rapidly toward nuclear power by using Westinghouse and General Electric reactor designs. With twice the population of Taiwan, Korea has about the same amount of installed nuclear capacity (Table 19), which it built under contract to Westinghouse and Atomic Energy of Canada. However, three additional reactors are under construction by Westinghouse and Framatome, and more are in the planning stage. In 1987, Combustion Engineering signed a contract to supply and fuel two 1000-MW PWRs for Korea, the U.S. company's first order in many years. With an even larger population than either Taiwan or Korea, the Philippines have one 0.62-GWe Westinghouse PWR that has yet to be licensed.

China's ambitious plans to build ten nuclear plants with a generating capacity of $10 \mathrm{GWe}$ by the tum of the century have now been cut back. But before the announcement, several years of discussions with contractors from nuclear nations had taken place. West Germany's KWU and Framatome of France had been negotiating for contracts worth about $\$ 1.6$ billion, and they expected China to spend twenty times that in the course of its planned nuclear expansion. ${ }^{57}$ It appears that of the several proposals under discussion with Western representatives, the only ones that will go ahead are the twin 985-MWe PWRs at Daya Bay, which are designed to supply Hong Kong. A hard currency shortage is widely believed to be a cause of the reversal in policy with regard to buying foreign nuclear technology. In the case of the Daya Bay reactors, which are now scheduled for completion in 1992 and 1993, sales of electricity to Hong Kong will be used to retire the debt associated with the construction of the plant. Unfortunately, that will be a short-lived source of hard currency because Hong Kong will cease to be a crown colony in 1997. However, without at least 6.5 GWe of new generating capacity by 1990 , China must expect power shortages to occur. So, in lieu of nuclear reactors, 18 new coal-fired stations with an aggregate rating of 6.5 GWe are planned.

One 300-MWe nuclear power reactor of Chinese design is now under construction at Qinshan in Zhejiang province. China is hoping to scale up the Qinshan plant design to $600 \mathrm{MWe}$ and, as much as possible, forego purchase of foreign equipment." It tentatively plans units of 10-600 MWe; however, coal remains an abundant alternative fuel. If the ten nuclear units were to require imported components, they too may be replaced by coal-fired plants.

Table 19. Nuclear energy in Asia (1986).

\begin{tabular}{lcccc}
\hline & China & Korea & Taiwan & Philippines \\
\hline Nuclear generation (bn kWh) & 0 & 26.1 & 26.9 & 0 \\
Nuclear generation $(\%)$ & - & 44 & $44^{*}$ & - \\
Installed nuclear capacity (GWe-net) & 0 & 5.4 & 4.9 & $0.62^{b}$ \\
Number of operable power reactors & 0 & 7 & 6 & 1 \\
Number of reactors under construction & 1 & 2 & 0 & 0 \\
Annual nuclear capaclty factor $(\%)$ & - & 78 & 61 & - \\
\hline
\end{tabular}

Estimated.

b Complete but not approved for operation. 


\section{Three Maverick Nuclear States: India, Brazil, and Argentina}

Among the less developed countries that have moved toward nuclear energy for power generation, India, Brazil, and Argentina stand out. All three have refused to sign the 1970 Non-Proliferation Treaty, and two rejected IAEA safeguard inspections on all of their facilities. At one time or another, all three have contemplated-if not built-fuel reprocessing and/or enrichment plants to avoid dependence on foreign fuel supplies (see Table 20). All three countries have uranium resources, with Brazil's reserves at $\$ 30 / \mathrm{lb}$ (as of December 31, 1985), putting it fourth in the free world behind Australla, South Afrtca, and Niger."

Investment in nuclear facilities in the three countries, combined with "go it alone" philosophy, has generated considerable concern for international organizations focused on proliferation issues. This has been particularly true in India and Argentina, where energy self-sufficiency without nuclear power has nearly been attained. In Brazil, hydroelectric power accounts for almost $85 \%$ of all power production, and, again, a need for nuclear power is not apparent. India relies principally on coal and hydropower to provide $95 \%$ of its electricity. Only in Argentina, where the source of more than $60 \%$ of power is oil- or gas-fired turbines, would there seem to be sound reasons for looking to nuclear power for future electrical supplies because domestic fossil fuels will ultimately be depleted.

\section{India}

The first power reactors in India were BWRs built by $\mathrm{GE}$ using enriched $\mathrm{UO}_{2}$ as fuel. Subsequent installations have been CANDUs, until the late 1960's supplied by the Atomic Energy Commission, Ltd, of Canada. These four reactors were subject to IAEA safeguard inspections. Not subject to IAEA inspections are the Madras 1 and 2, 220MWe CANDUs designed and built by the Indian Department of Atomic Energy in the following decade, nor are the several research reactors that have operated at the Bhabha Atomic Research Centerat Bombay. All future Indlan reactors are expected to be an indigenous design that uses heavy water as coolant and moderator and natural uranium as fuel, thus obviating the need for uranium enrichment. CANDUs produce prodigious amounts of plutonium compared to light-water reactors. ${ }^{\infty}$ India's capabllity of extracting plutonium from spent fuel rods was brought to the world's attention by the detonation of a nuclear bomb at Pokharan in the Rajasthan desert in 1974. The 40-MWe Cirus reactor built in 1963 with Canadian help is said to have produced the fissile plutonium-239 for the explosion. ${ }^{11}$ Not surprisingly, by 1985 India began operating an experimental 14MWe fast breeder reactor (FBR) that uses plutonium-uranium carbide as fuel, and the country is reported to be working on a $500-\mathrm{MWe}$ prototype of the same design.

Table 20. Nuclear power installations (1986).

\begin{tabular}{llll}
\hline & India & Brazil & Argentina \\
\hline Number of operable power reactors & 7 & 1 & 2 \\
Number of reactors under construction & 4 & 2 & 1 \\
Installed nuclear capacity (GWe-net) & 1.27 & 0.63 & 0.94 \\
Signatory to Non-Proliferation Treaty & No & No & No \\
IAEA enfe-guards on all nuclear facilities & No & No & No \\
Reprocessing facilities & Yes & Construction & Under \\
& & postponed & construction \\
Enrichment facilities & No & Construction & Under \\
& & postponed & construction \\
\hline
\end{tabular}




\section{Brazil}

Brazil's ambitious nuclear energy program inaugurated under the military government has faltered as a consequence of inflation and the nation's econornic crises. In 1975, Brazil negotiated a nuclear pact with West Germany that provided eight reactors and the transfer of European ultracentrifuge enrichment technology. At that point, Angra I, a 657-MWe (gross) PWR of Westinghouse design was under construction. Under pressure from its allies, Weat Cermany withdrew its offer of the ultra-centrifuge technology and instead offered the untested Becker jet nozzle enrichment process. Tension with its neighbor Argentina undoubtedly influenced Brazil's decision to pursue all aspects of the nuclear fuel cycle, although both nations are signatories of the unratified 1967 Thatelolco Treaty that bans weapons or tests throughout Latin America.

Brazil has expresued a desire to rencgotiate the 1975 agreement with West Germany, as there is only a remote possibility that the eight resctors will be purchased. Angra 1 produced its first power in 1982, but it has been plagued with technical defects and litigation over evacuation plans for nearby inhabitants. It has been nicknamed "Vagalume," Portuguese for lightning bug, because of its penchant for going on and off. Construction of two additional reactors, Angra 2 \& 3 (1.3 GWe each), started in 1971 and 1976, respectively, under contract with West Germany's KWU; but they are not completed yet. In view of Brazil's vast hydroelectric resources, a large nuclear generation program is unneceseary. In addition to backing down on its plans for reactors, Brazil announced in 1986 that it postponed plans for reprocessing spent reactor fuel and for construction of the Becker enrichment process site. Nonetheless, it has been reported repeatedly that both reprocessing and enrichment using cannibalized and upgraded German centrifuge equipment continue at the government Instituto de Pesquisas Energeticas e Nucleares on the outskirts of Seo Paulo. 20 Brazil claims that the laboratory is outside of intermational jurisdiction because it was built without assistance. Nominally, its objective is to develop a small nuclear reactor for submarines.

\section{Argentina}

Argentina is regarded as the most advanced nuclearnation in the Western Hemisphere after the
U.S. and Canada. The reputation is not based on the size of its civilian nuclear power program, for it consists of only two pressurized heavy watermoderated reactor (PHWR) plants (335 and 600 MWe). A third plant is scheduled to become operational in 1990. The operating reactors using natural uranium as fuel, which were designed by KWU and the Atomic Energy of Canada, Ltd., are under IAEA safeguards standards.

It is the remainder of the Argentinian nuclear program that has at once earned it the reputation of rapid progress while giving the appearance that its objectives reach beyond the civilian sector: reprocesing factlity using West German technology is scheduled for completion in 1989; an enrichment plant at Pilcaniyeu belleved to use a gaseous diffusion process 4 is expected to start production in 1987; a heavy-water plant at Atucha is also under construction. Argentina has long strived for complete independence of foretgn supplies and technology for completing its nuclear fuel cycle. Because none of these plants is under IAEA safeguards, and Argentina has refused to sign the NonProliferation Treaty, the country has attracted world attention as a possible nuclear weapon state. It has repeatedly stated that it reserves the right to develop nuclear energy for peaceful purposes without intervention. And, as a further assertion of its independence, it has initiated agreements and discussions to sell nuclear technology to many developing countries, such as Peru, Iran, Algeria, Cuba, and perhaps Israel. ${ }^{\omega}$ In 1987, Argentina signed an agreement with Iran to modify a 5-MW research reactor $s 0$ as to be able to use uranium enriched to $20 \%$ instead of $93 \%$. Argentin is to supply the enriched uraniu'n and the new core, with the IAEA acting as an intermediary. In another agreement, Argentina, Spain, and West Germany will complete the $1300-\mathrm{MWe}$ PWR at Bushehri, which was started prior to the Iranian revolution. 's

The civilian side of nuclear reactor technology has also been the focus of increased research and development in the last few years. In March 1987, the country announced a new 380-MW PHWR in cooperation with KWU that has a higher degree of safety than earlier PHWRs. Like the CANDU PHWRs, it is specially designed to be refueled while operating. It seems likely that this reactor, called ARGO, will be the prototype of future installations, the Argentinians thereby achieving almost complete independence from the usual nuclear technology cuppliers. 


\section{Nuclear Energy in South Africa and Pakistan:}

\section{Two More Maverick Nuclear States}

The history of the development of power reactors in both South Africa and Pakistan (see Table 21) has aroused in supplier nations considerable concern on the subject of possiblediversion of potential fissile materials for bomb-making activities.

In South Africa, the two Westinghousedesigned, Framatome-built PWRs are open to inspection by the IAEA. Construction of the two reactors started in 1977, but they did not become operational untl 1984 and 1985 because of delays associated with finding a source of enriched uranium. The U.S. refused to supply enriched fuel under 1970's agreement because South Afric refused to sign the U.S. Non-Proliferation Treaty. By the time of the U.S. decision, South Africa had already shipped uranium to the U.S., and it is reported that South Africa had to absorb the $\mathbf{\$ 3 0}$ million loss." Ultimately, the country obtained surplus uranium from Switzerland and Belgium, ironically through U.S. brokers. The uranium was then enriched by EURODIF and another unnamed consortium and assembled into fuel rods in France." In 1975, South Africa began building a pilot enrichment plant. In 1981, the South African energy minister announced with pride that the Safari I research reactor, built with U.S. help in the early 1960 's, was running on fuel produced at the facility." Subsequently, South Africa undertook the construction of a semi-industrial-scale (300 tSWU/yr) enrichment plant at Valindaba near Pretoria; it is scheduled to become operational in 1987. The plants use the "helikon" enrichment process (jet-nozzle or stationary-wall centrifuge). ${ }^{\text {T }}$ The purpose of this process is reputedly to supply fuel for the nuclear power plants, but negotintions in 1986 between the LAEA and South Africa to put the plant under international safeguards broke down over South Africa's demands to withdraw some enriched uranium for other uses, such as fuel for nuclear submarines."

Presently, the two reactors can supply about $6 \%$ of South Africa's electricity requirement. The country is well endowed with both urnium and coll resources. Ability to obtain or produce sufficient enriched fuel rods may dictate whether South Africa will construct additional reactors or continue to rely heavily on coal for future power needs.

Pakistan has had severe electrical shortages, common in developing countries having rapid industrialization and agriculture development. It is aggresively building oil-, gas-, and coal-fired generating plants that use both domestic and imported fuels. To date, the nuclear power option has not been pursued vigorously because of numerous problems associated with the 1972 start-up of its heavy-water reactor built with Canadian assistance. Although the plant was under the IAEA safeguards program, after Pakistan contracted with a French firm in 1973-74 to build a large reprocessing plant at Chashma, Canada discontinved shipments of the natural uranium fuel to Pakistan, as it was the Canadians' judgment that development of a plutonium weapon was in the offing. The reactor had to be shutdown for three years, but ultimately Niger supplied the requisite natural uranium through direct purchase and through Libya as an intermediary?

Pakistan also built a henvy-water upgrading plant in onder to come to grips with loss of its supply of heavy water. The planit is now operating

Table 21. Nuclear power installations in South Africa and Paklstan (1906).

\begin{tabular}{lcc}
\hline & South Africa & Pakistan \\
\hline Number of operable power reactors & 2 & 1 \\
Number of reactore under construction & 0 & 0 \\
Installed nuclear capacity (GWe-net) & 1.84 & 0.13 \\
Signatory to Non-Proliferntion Treaty & No & No \\
IAEA safeguards on all nuclear facllities & No & No \\
Reprocessing facilities & No & Yes \\
Enrichment facilities & Yes & Yes \\
\hline
\end{tabular}


but producing only $80 \mathrm{MW}$ of its rated $137-\mathrm{MW}$ capacity. Under pressure, the French contractor for the reprocessing plant withdrew in 1978; however, the Pakistanis set out to finish the plant. At about the same time, Pukistan began to build an enrichment plant at Kahuta. The enrichment plans were allegedly smuggled from the URENCO plant in the Netherlands in 1975 by A. Q. Khan, currently Chairman of the Pakistan Atomic Energy Commission, who was then in the enrichment consortium's employ. ${ }^{73}$ It is reported that some plans for centrifuge components as well as for their fabrication were exported to Pakistan from West Germany and Switzerland before the unlicensed exports came under investigation in 1986.74 As Pakistan had no reactor that used elther plutonium or enriched uranium, world opinion agreed that the country had set about to develop a nuclear bomb to match its traditional enemy India's feat in the early 1970's. With this background, negotiations with the principal nuclear suppliers for the purchase and construction of additional Pakistani nuclear power capacity proved difficult if not impossible. On this account, Pakistani President General Zia ulHaq at the end of 1986 formally directed the country's atomicenergy commisolon to begin work on the design and manufacture of an indigenous nuclear reactor. ${ }^{75}$

\section{Canada's Large Nuclear Program}

With nearly 11-GWe installed nuclear capacity at the end of 1986, Canada's nuclear power program is smaller than that of a half dozen countries. Yet it is remarkably large in view of the country's relatively small population and its indigenous natural resources available for power production. Currently, $67 \%$ of net power production is hydroelectric and nearly $15 \%$ is nuclear (Table 22). By 1990, when installed nuclear capacity reaches 13.6 GWe, the amount of nuclear capacity per capita will be exceeded only by that of Sweden and France (Fig. 2). In contrast to those countries, Canada is richly endowed with oil and gas, which it exports as surplus, and other yet to be fully developed resources, such as tar sands. Understandably, most reactors in Canada are located in the populous eastem part of the country that is distant from the bulk of domestic resources.

The CANDU reactor is the mainstay of the Canadian nuclear industry. Its design was financed primarily with government money and is vended by the state-owned Atomic Energy of Canada, Ltd. Its manufacture and assembly is in private hands. All reactors currently operating in Canada are of the CANDU design, as are all reactors under construction. Thus, Canada has realized what many countries believe is an important contribution to the production and operation of safe reactorsuniformity of design and construction. Thereactor is a PHWR design that uses natural $\mathrm{UO}_{2}$ as fuel and $\mathrm{DO}_{2}$ as coolant and moderator. Its configuration permits on-line refueling, which reduces downtime and fosters high capacity factors, which on average have exceeded those for the diverse reac- tors in the U.S. In nuclear power plant performance, the CANDUs have been consistently in the top half of a world wide list. ${ }^{7677}$ The small CANDU at Rolphton is the oldest operating reactor in North America.

Experience and reliabllity have enabled the Canadian government to develop an export market. CANDUs are operating in India, Argentina, and Korea; two additional PHWR reactors are under conatruction in India and five in Romania. The PHWRs produce almost twice as much plutonium per kWe as light-water reactors ${ }^{0}$; thus, they have always been a concern with respect to proliferation of weapon-grade materials.

The 1952 accident at an experimen?al nuclear power reactor at Chalk River, Ontario, resulting in a partial melting of the uranium fuel, caused little furor at the time compared to what could be expected in 1987. The incident, though not forgotten, did not materially impede the development of nuclear power in Canada.

Table 22. Electrical generation in Canada (1986).

Total electrical generation (bn kWh) 507

Nuclear contribution (bn kWh) $\quad 74.5$

Nuclear power (\%)

Hydropower (bn kWh)

301 (1985)

Hydropower (\%)

67 (1985)

Installed nuclear capacity (GWe-net) 11

Number of operable power reactors 18 


\section{Nuclear Reactors in Mexico: Without High Priority}

Before the size of the 1970 Reforma oil discoveries in the Gulf of Mexico was fully assessed, Mexican President Jose Lopez Portillo announced a plan to put 20 nuclear reactors in operation by the end of the century. In 1969, the first orders were placed with GE for twin 654-MWe (net) BWRs. The original cost estimates were on the order of $\$ 263$ million, and completion was anticipated in three years. However, by May 1987, fuel was yet to be loaded into the first Lagun Verde reactor near Verz Cruz on the Gulf of Mexico, and the second unit was about $50 \%$ complete. It is expected that about $\$ 3$ billion will be expended on the project. The initial enthusiasm, construction delays, and cost overruns have counterparts throughout the nuclear wor'd. In Mexico, the giant Reforma and Gulf of Campeche oil discoveries played an important role in causis $g$ a tumabout in federal policy towand development of nuclear reactors because they simultaneously mitigated a serious longrange energy problem and siphoned federal investment monies off for development of the oil fields. In 1982, after a vigorous competition for contracts to build additional power plants, all Lids were returned unopened to the foreign bidders. This followed the precipitous fall in world oil prices that left the Mexican government in severe financial straits. To add to the delays, every Mexican presi- dent since 1969 has had to make a decision about whether Laguna Verde or any other reactor project should go forward-hence the many delays once construction started at Laguna Verde. In the interim, both Three Mile Island and Chernobyl muted the enthusiasm of even the country's greatest champions of nuclear power. The reasons relate to the largenumber and type of industrial accidents that have occurred in Mexico during the past few decades. In the oil fields alone, 172 workers have been killed during the past fouryears." The numerous delays at Laguna Verde have led to the shift of foreign-trained reactor operators to administrative work, and ultimately to a need for additional reactor trainees. This, in tuni, has intensified the concerns over reactor safety.

Ninety percent of Mexico's energy needs currently are met by petrolsum. Although the 1970 discoveries will be reaching depletion by the turn of the century, Mexico is blessed with untapped hydroelectric capacity. In addition, no substantial use has been made of the associated gas discovered with the oil. Both resources could be developed to provide power once oil no longer is a reliable option. It seems unlikely that the grandiose nuclear schedule envisioned in the early 1970 's will be revived before well into the next century.

\section{Conclusions}

While the Chernobyl accident alarmed the world in 1986, by the end of the ensuing year the public attitude loward nuclear power had not changed markadly from what it was before the reactor disaster. One notable result was that many countries reviewed the safety and standards at their operating reactors despite the fact that few of them resembled the U.S.S.R. graphit:-moderated units. With few exceptions, one being the $\mathrm{N}$-reactor at Hanford, Washington, the reactors were given a clean bill of health. Some countries (e.g., Finland, Holland, and Greece) have canceled or postponed plans to acquire new reactors since Chernobyl; however, review of the situation suggests that such action was contemplated for a variety of reasons before the accident. In fact, reconsideration of the use of nuclear reactors for power production has been underway throughout the world for a decade or more.
As is well known, there has not been a new reactor order from the $\mathrm{U}$. $\therefore$. since 1978. A similar situation prevails in many countries-e.g., Sweden, Switzerland, Italy, and Spain. Reasons are numerous and often unique to the energy situation in individual countries. Two factors stand out. One is the cost of nuclear reactors and the rest of the fuel cycle, which has steadily climbed to the point where nuclear energy is no longer competitive with conventional fuels for power production. The other is lowered demand estimates for electrical power in many countries for thenextcentury. In 1972 , the year when aggregate world reactor orders reached a peak as measured by total GWe, estimates of futureelectrical demand were so large that conventional fossil fuels were ruled out, especially if they had to be imported.

In the last decade, the nuclear power industry has been "politicized" in many countries. Stands 
on nuclear power usage have been election issues in West Germany and Sweden as well as in other nations. Governments and agencies have become increasingly sensitive to the public's objections to nuclear reactors on the basis of safety and proliferation of nuclear materials. In Italy, for example, the effect has been to delay decisions relating to siting and construction.

The wisdom of phasing out oil as a fuel for power production still prevails, but the alternative in many countries has been coal rather than nuclear power even in thosenations that lack an indigenous supply. Coul is also a common choice when additicnal generating capacity is needed or when existing nuclear plants have reached the end of their useful lives. Countries that are building or planning new coal-fired electrical generating capacity include the U.S., Sweden, Finland, Netheriands, Italy, Denmark, Greece, Japan, Ireland, China, and others. In several countries, e.g., U.K. and West Germany, existing coal-fired plants are in the process of being upgraded for more efficient combustion and pollution abatement.

Australin has become the largest steam conl* exporter in the world, although it has only an estmated $7 \%$ of the world's recoverable coal reserves, ${ }^{\infty}$ and it is expected to dominate trade at least through 1995. Both Chin and Colombia are building up export markets; in contrast, the US. has lost some of its steam coal customers because its prices and railrond freight rates are higher than those of other exporters. The world's coal reserves and undeveloped resources are large enough to meet the demand well into the next century; however, increased use of covl and lignite carries environmental consequences on both a local and a global scale that in the end may limit its use. Before that point is reached, the turn to coal as an alternative to nuclearpower production is leading to compettion for low-sulfur coal on international markets.

Observers have long maintained that uniformity of reactor design could contribute to the safety of the indusity as well as to cost reductions during construction. With a single design, the experience and expertise in all parts of the industry n ould increase manyfold over that associated with operation of many reactor types. Other advantages

\footnotetext{
- Steam conl is used principally for power production. The U.S. is the world's largest exporter of coking coal, often called metallurgical coal. Coking coal, which sonstitutes the largest share of our coal exports, is a premium gradebituminous conl, low in both ash and sulfur.
}

would as urue in the course of training operators and reducing the human factor, which has been very important in the major accidents to date. Some countries with an indigenous nuclear industry, such as France and Canada, have pursued that goal successfully. But in other countries such as the U.S., a plethora of types was developed, many of which are still in operation. Nonetheless, on a world wide basis, the objective of uniformity is now being appronched, partly because of the demise of many reactor manufacturers and the retirement of one-of-a-kind reactors built in the early days of the technology. By 1986, the pressurized water reactor had become the most common. Twice as many PWRare in operation or under construction as its nearest competitor, the bolling water reactor (BWR). The trend towand uniformity will continue as countries such as the U.S.S.R. and the U.K. discontinue building their graphite-moderated reactors and Magnoxes. Because there is considerable diversity in the designs of PWRs by the main manufacturers (Westinghouse, Framatome, Kraftwerk Union, and Mitsubishi), uniformity can not be realized, only approached, at this stage of development.

Although there was a resurgence of interest in nuclear power following the disruptions in the world oil supply in 1973-74 and 1979-80, orders for nuclear power plants continued to decline during the 1970 's. At theend of 1986 , there were 530 power reactors worldwide elther in operation or on order. $^{2}$ Of these, the largest number (82) was for the U.S.S.R. with another 44 either exported or destined for export by US.S.R.'s Atomenergoexport. Another 133 power reactors are under construction in the world. Noteworthy is the fact that the less developed countries account for more than $11 \%$ of the total under construction, which is in contrast to their much smaller share of operating reactors. Collectively, the less developed countries have about $3 \%$ of the total world operating experience with power reactors, and many have only one or two within their boundaries. Thus, as reactors become operational in countries such as Cuba, Mexico, and Iran, the combination of inexperience and lack of technical resources augurs ill for safety and reliability. The situation is compounded by the few countries such as Pakistan and Argentina that operate reactors without IAEA safeguards and, consequently, without support from supplier countries.

The world reactor industry is also haunted by possible proliferation of nuclear weapons as a consequence of enrichment and reprocessing facilities 
built nominally to service the power industry in countries such as India, Pakistin, Argentina, South Africa, and Brazil.

In summary, reactor accidents in any country or evidence of diversion of nuclear materials for military purposes would further influence global opinion. Nuclear power began to fall out of favor in the U.S. before the Three Mile Island (1979) and Chernobyl (1986) accidents, generally for economic reasons. Escalating costs in the U.S. are owing to \& variety of sometimes unique causes. Among them are public objections leading to construction and "atart-up" delayn, government regulations, multiple vendors and dedigns, and, at one time, escalating intered rates. While such factors heretofore have been less important in many of the nuclear countries, they are beginning to influence reactor costs and, ultimately, declsions relating to power plant construction worldwide. Even nations such as France, which are committed to using nuclear energy for power production, may be shaken in pursuit of their objectives if another major acddent occurs. On the other hand, assuming that the course of the nuclear industry is uneventful until the mid 1990's, when a new demand for generating capacity is expected in Europe, the industry may see a refuvenation. In the U.S., new onders for reactors could be expected at about the same time; however, they will likely be for smaller plants inherently designed for sufety. 


\section{Data Sources for Tables}

The principal sources of the data appearing in the tables are given below. Minor differences exist between national and international agencies reporting for 1986. It is not possible to know the reasons for the differences; in some instances, the differences can be attributed to revisions, and in other cases it appears that they reflect unspecified differences in reporting procedures. For example, one difference may be between gross and net electrical production, or it may roflect whet ner or not private power prorluction within a country is included. Additional sources are noted in individual tables.

Total Electrical Generation

Monthly Energy Review, U.S. Department of Energy, Energy Information Agency, 1987 (U.S.).

Financial Times European Energy Report 235, 9, March 20, 1987 (Europe).

Nuclear Generation

Nucleonics Week 28, 9, February 5, 1987.

Nucleonics Week 28, 6, April 9, 1987.

Percent Nuclear Power Generation

Finencial Times European Energy Report 235, 9, March 20, 1987 (Europe).

Mont?ty Energy Reoiew, U.S. Department of Energy-Energy Information Agency, 1987 (U.S.). Nucleonics Week 28, 6, April 9, 1987 (Other countries).

Installed Nuclear Capacity (GWe-net) and Number of Operable Reactors

World Nuclear Industry Handbook 1987, Nuclear Engineering International, November 1986 Supplement, p. 140.

Nuclear Newos 30, 61, February 1987.

Installed Electrical Capacity (GWe-net)

Electricity in IAEA Countries (International Energy Agency, Paris, France), 1985, 377 pp. 


\section{References}

1. Nuclear News 30, 18 and 79, February 1987.

2. Nuclear Fuels Policy (The Atlantic Council of the United States,Washington, DC, 1976), AppendixA, p. 65.

3. Nuclear Engineering 30, 3, August 1985 Supplement.

4. E. J. Hanrahan, Nuclear Power Growth-Enrichricent and Uranium Requirements, 1974 to Year 2000, Uranium Industry Seminar (U.S. Atomic Energy Commission, Grand Junction, CO, October 22, 1974).

5. E. J. Hanrahan, U.S. Unanium Requirements, The Unonium Industry Seminar (U.S. Energy Research and Development Administration, Grand Juncton, CO, October 19, 1976).

6. Statistical Data of the Umanium Industry, U.S. Department of Energy, Grand Junction, CO, GJO-100(81), (January 1, 1981), p. 82.

7. Commercial Nuclear Power: Prospects for the U.S, and the World, Department of Energy, DOE/EIA-0438 (1986), p. 29.

8. World Nuclear Industry Hardbook 1987, Nuclear Engineering International, November 1986 Supplement.

9. V. Baum, "Nuclear Power: Status and Prospects," Petroleum Economist 52, 360, October 1985.

10. "Soviet Starts Operation of Two New Reactors," New York Times, December 21, 1966, Pt. I, p. 15.

11. National Energy Policy Plan Projections to 2010, Department of Energy, DOE/PE-0029/3 (December 1985), pp. 3-22.

12. Financisl Times European Energy Report 169, iv, July 27, 1984.

13. Financial Times European Energy Report 201, 7, Noveniber 1, 1985.

14. Financial Times European Energy Report 213, 10, May 2, 1986.

15. Petroleum Economist 53, 147, April 1986.

16. W. Swreet, "Despite Super-Phenix Startuf, Outlook for Breeders is Poor," Physics Todry 39, 53, September 1986.

17. D. Albright, "World Inventories of Plutonium," Nuclear Terrorism: Defining the Threat, P. Leventhal, Y. Alexanders, eds. (Pergamon-Brascey's, McLean, VA, 1986).

18. B. Keller, "The 1960 Disaster at Chernobyl: A Year Later, Lessons are Drawn," New York Times, April 26, 1987, p. 1.

19. U.S.S.R. Report-Energy, Foreign Brondcast Information Service, JPRS-UNF. 86-011 (December 9, 1986), p. 34.

20. W. Lepkowski, "U.S.S.R. Reaches Takeoff in Nuclear Power," Chemical-Engineering Notus, November 6, 1978, pp. 33-34.

21. U.S.S.R. Report-Energy, Foreign Brandcast Information Service, JPRS-UEN-86-005 (March 7, 1986), p. 22.

22. Financial Times European Energy Report 230, 19, January 9, 1987.

23. Nucleonics News 23, 6 and 9, April 9, 1987.

24. B. Newman, "Radioactive Winds Singe Polish Life, But Encourage Spirited Public Debate," Wall Street Joumal, April 23, 1987, p. 23.

25. T. Stauffer, "Why Nuclear Power is Cheaper," Energy Daily 15, 1, March 26, 1987.

26. P. Treuthardt, The Valley Times, March 1, 1987, Pt. B, p. 8.

27. M. Hansberg, and E. Mignot, "The Competitive Position of Nuclear Power in France," Proc. of the Tenth Annual Symposium of the Unanium Institute, London (September 3-5, 1985).

28. Nuclear Necos 30, 61-2, February 1987.

29. Petroleum Economist 53, 146, April 1986.

30. D. Dickson, "Super-Phenix Springs a Leak," Science 236, 248, April 17, 1987.

31. R. L. Hudson and T. Koth, "A Year Later, Mishap at Chernobyl Damps Atom-Power Industry," Wall Street Joumal, A pril 23, 1987, p. 1.

32. "PWR is Britain's cup of tea," Energy Daily 15, 1, January 28, 1987.

33. Financial Times European Energy Report 232, 7, February 6, 1987. 
34. P, Almond, "Nuclear Mant To"rism Steams Protestors," The Washington Times, April 24, 1987, Pt. A, p. 8.

35. "Fueling the Nuclear Debate," Mining Joumal 307, 1, December 12, 1986.

36. Financial Times Europenn Energy Report 226, 5-6, October 31, 1986.

37. Financial Times European Energy Report 239, 7, May 15, 1987.

38. Financial Times European Energy Report 217, 14-16, June 27, 1986.

39. Financial Times European Energy Report, 232, 3, February 6, 1987.

40. Financial Times Europenn Energy Report 150, 7, October 28, 1983.

41. Financial Times European Energy Report 236, 7, April 3, 1987.

42. 1984 Energy Statistics Yearbook (United Nations, New York, 1986), 141 pp.

43. Financial Times Europenn Energy Report 223, 18, 23, May 1, 1987.

4. U. Belelli, "Public Acceptance and the Nuclear Progranume in Itoly," Uranium and Nuclear Energy: 1985 10, 101-107. (Tranium Institute, London, 1985).

45. Fihancial Times Europwn Energy Report 231, 4, January 23, 1987.

46. Financial Times Eumpean Energy Reolew 233, 1-2, February 20, 1987.

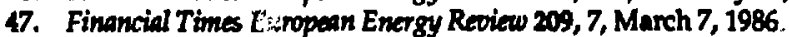

48. Fìancial Times European Energy Report 214, 8, May 16, 1986.

49. Financial Times European Energy Report 235, 8-9, March 20, 1987.

50. Finuncial Times Europenn Electricity Quarterly, 4, May 1986.

51. Reoiew of New Encrgy Technology, Sept/Oct 1985, p. 12.

52. Nucleonics Week 28, 9, February 5, 1987.

53. S. Russex:, "GE's i. an Jose Unit Gets Big Japanese Order," Sar Francisco Chronicle, May 15, 1987, p. 43.

54. P. J. Mellinger, K. M. Harmon, and L. T. Lakey, A Summary of Nuclear Fuel Reprocessing Activities in the World, Battelle NW Laboratory, Richlard, WA, PNL-4981 (November 1984), p. 10.

55. Nucleonics Waek 26, 7, September 5, 1985.

56. Energy Daily 15, 2, April 10, 1987.

57. Petroleum Economist 53, 303, August 1986.

58. Nucleonics Week 27, 3, June 26, 198.

59. Uranium: Resources, Production and Demand (Organization for Economic Cooperation a Development, Nuclear Energy Agency, Paris, 1986).

60. J. Hovirigh, Fission Power-A Seanch for a "Second-Generation" Reactor, Lawrence Livermore National Laboratory, Livermore, CA, UCID-20015 (July 8, 1985).

61. S. Dubey, "India, Keeping its Nuclear Options Open, Moritors Arms Program in Neighboring Pakistan with Concem,' Wall Street Joumal, November 26, 1984, p. 38.

62. M. R. Benjamin, "Brazil Takes Step toward Developing Nuclear Weapons Potential," Washington Post, February 3, 1983, Pt. A, p. 29.

63. R. House, "Brazil Steps Back from Race to Build Nuclear Weapons," Washington Post, August 28, 1986, Pt. E, p. 1.

64. J. Walsh, "Argentina Formulates Nuclear New Deal," Science 223, 669-70, Feb. 17, 1984.

65. Nucleonics Week 27, 6-7, May 29, 1986.

66. "Argentina to Help Iran with A-Plant," San Francisco Chronicle, May 19, 1987, p. 9.

67. M. Sullivan, "S. Africa's Nuclear Industry Queried on Finances, Safety," The Washington Times, Feb 25, 1985, Pt. A, p. 7.

68. T. OToole, "U.S. Firms Help South Africa Get Uranium," Washington Post, April 13, 1982, Pt. A, 2.5.

69. P. Van Slambroack, Christian Science Monitor, October 22, 1981, p. 1.

70. K. M. Harmon and L. T. Lakey, International Source Pook Nuclear Fuel Cycle Research and Deoelopment 2, Battelle Pacific NW Lab, Richland, WA, PNL-2478 Rev. 2 (April, 1983), p. SF-2.

71. W. Pincus, "S. Africa Uranium Plant Reported Ready," Los Angeles 'fimes, October 2, 1986, Pt. I, p. 6.

72. H. Freeman, "Pakistan: Joining the Nuke Club," Lss Angeles Times, December 1, 1985, Pt. III, p. 2.

73. L. King, "No bomb in Pakistan Nuclear Program, Zia Insists," Energy Daily 15, 4, April 6, 1987.

74. Financial Times European Energy Report 239, 1, May 15, 1987. 
75. Nucleonics Weat 27, 3, November 13, 1986.

76. Nucleonics Weat 27, 1, February 6, 1986 .

77. Nucleonics Week 28, 10, February 5, 1987.

78. Nucleonics Weck 27, 11, October 9, 1986.

79. D. William, "Safety Fears Cloud Future of Mexico's First Nuclear Plant," Los Angeles Times, Jan. 13, 1987, Pt. I, p. 12.

80. International Energy Outlook 1985, Department of Energy, DOE/EIA-0484 (1985), p. 38. 